\title{
Identification of uterine ion transporters for mineralisation precursors of the avian eggshell
}

Vincent Jonchère, Aurélien Brionne, Joël Gautron and Yves Nys

\begin{abstract}
Background: In Gallus gallus, eggshell formation takes place daily in the hen uterus and requires large amounts of the ionic precursors for calcium carbonate $\left(\mathrm{CaCO}_{3}\right)$. Both elements $\left(\mathrm{Ca}^{2+}, \mathrm{HCO}_{3}^{-}\right)$are supplied by the blood via trans-epithelial transport. Our aims were to identify genes coding for ion transporters that are upregulated in the uterine portion of the oviduct during eggshell calcification, compared to other tissues and other physiological states, and incorporate these proteins into a general model for mineral transfer across the tubular gland cells during eggshell formation.
\end{abstract}

Results: A total of 37 candidate ion transport genes were selected from our database of overexpressed uterine genes associated with eggshell calcification, and by analogy with mammalian transporters. Their uterine expression was compared by qRTPCR in the presence and absence of eggshell formation, and with relative expression levels in magnum (low $\mathrm{Ca}^{2+} / \mathrm{HCO}_{3}^{-}$movement) and duodenum (high rates of $\mathrm{Ca}^{2+} / \mathrm{HCO}_{3}^{-}$trans-epithelial transfer). We identified overexpression of eleven genes related to calcium movement: the TRPV6 $\mathrm{Ca}^{2+}$ channel (basolateral uptake of $\mathrm{Ca}^{2+}$ ), $28 \mathrm{kDa}$ calbindin (intracellular $\mathrm{Ca}^{2+}$ buffering), the endoplasmic reticulum type 2 and $3 \mathrm{Ca}^{2+}$ pumps (ER uptake), and the inositol trisphosphate receptors type 1, 2 and 3 (ER release). $\mathrm{Ca}^{2+}$ movement across the apical membrane likely involves membrane $\mathrm{Ca}^{2+}$ pumps and $\mathrm{Ca}^{2+} / \mathrm{Na}^{+}$exchangers. Our data suggests that $\mathrm{Na}^{+}$transport involved the SCNN1 channel and the $\mathrm{Na}^{+} / \mathrm{Ca}^{2+}$ exchangers SLC8A1, 3 for cell uptake, the $\mathrm{Na}^{+} / \mathrm{K}^{+}$ATPase for cell output. $\mathrm{K}^{+}$uptake resulted from the $\mathrm{Na}^{+} / \mathrm{K}^{+}$ATPase, and its output from the $\mathrm{K}^{+}$channels $(\mathrm{KCNJ} 2,15,16$ and KCNMA1).

We propose that the $\mathrm{HCO}_{3}^{-}$is mainly produced from $\mathrm{CO}_{2}$ by the carbonic anhydrase 2 (CA2) and that $\mathrm{HCO}_{3}^{-}$is secreted through the $\mathrm{HCO}_{3}^{-} / \mathrm{Cl}^{-}$exchanger SLC26A9. $\mathrm{HCO}_{3}^{-}$synthesis and precipitation with $\mathrm{Ca}^{2+}$ produce two $\mathrm{H}^{+}$. Protons are absorbed via the membrane's $\mathrm{Ca}^{2+}$ pumps ATP2B1, 2 in the apical membrane and the vacuolar $\left(\mathrm{H}+\right.$ )-atpases at the basolateral level. Our model incorporate $\mathrm{Cl}^{-}$ions which are absorbed by the $\mathrm{HCO}_{3}^{-} / \mathrm{Cl}^{-}$exchanger SLC26A9 and by $\mathrm{Cl}^{-}$channels (CLCN2, CFTR) and might be extruded by $\mathrm{Cl}^{-} / \mathrm{H}^{+}$exchanger (CLCN5), but also by $\mathrm{Na}^{+} \mathrm{K}^{+} 2 \mathrm{Cl}^{-}$and $\mathrm{K}^{+} \mathrm{Cl}^{-}$cotransporters.

Conclusions: Our Gallus gallus uterine model proposes a large list of ion transfer proteins supplying $\mathrm{Ca}^{2+}$ and $\mathrm{HCO}_{3}^{-}$and maintaining cellular ionic homeostasis. This avian model should contribute towards understanding the mechanisms and regulation for ionic precursors of $\mathrm{CaCO}_{3}$, and provide insight in other species where epithelia transport large amount of calcium or bicarbonate.

Keywords: Ion, Mineral, Calcium, Transporter, Uterus, Eggshell, Chicken

\footnotetext{
*Correspondence: yves.nys@tours.inra.fr

INRA, UR83 Recherches Avicoles, F-37380, Nouzilly, France
} 


\section{Background}

Biomineralisation is a process by which living organisms develop mineral structures to perform a variety of roles related to support, defence and feeding. Amongst these, a large number of animals (birds, molluscs, foraminifera, corals, sea urchins) mineralises by co-precipitation of calcium $\left(\mathrm{Ca}^{2+}\right)$ and carbonates $\left(\mathrm{CO}_{3}^{2-}\right)$ to form a protective shell or a skeleton. The prerequisite for shell mineralisation is the supply of large amounts of $\mathrm{Ca}^{2+}$ and $\mathrm{CO}_{3}^{2-}$ in a limited extracellular milieu by trans-cellular transport, requiring the presence of ion channels, ion pumps and ion exchangers. In Gallus gallus, eggshell formation takes place daily in the hen uterus and is one of the most rapid mineralisation processes [1]. It requires large amount of calcium carbonate $\left(\mathrm{CaCO}_{3}\right)$ as the hen exports the equivalent of her body weight as eggshell in one year of egg production $(>1.5 \mathrm{~kg})$. Both elements $\left(\mathrm{Ca}^{2+}\right.$ and $\left.\mathrm{HCO}_{3}^{-}\right)$are not stored in the uterus but are continuously supplied during eggshell formation by the blood plasma via trans-epithelial transport taking place across the uterine glandular cells [2-4]. Early studies determined the ion concentrations of the uterine fluid, which bathes the eggshell and changes during the sequential stages of calcification (Table 1) [5], identified several proteins involved in ion transport [3,6,7], and recorded changes in ion fluxes across the uterine epithelium in response to ion transporter inhibitors [8-10]. These classic approaches led to a hypothesis concerning the mechanisms of ion transfer through the uterine glandular cells (Figure 1; [1]). In hens, the $\mathrm{Ca}^{2+}$ blood (1.2 $\mathrm{mM})$ and epithelial cell concentrations $\left(10^{-4} \mathrm{mM}\right)$, suggest that $\mathrm{Ca}^{2+}$ entry in cell is passive via a $\mathrm{Ca}^{2+}$ channel, which remains unidentified. The intracellular $\mathrm{Ca}^{2+}$ transport through the cell involves $28 \mathrm{kDa}$ calbindin $[3,11,12]$. The $28 \mathrm{kDa}$ calbindin expression is greatly upregulated during eggshell formation and falls after suppression of calcification (by premature egg expulsion), suggesting a very close relationship between

Table $1 \mathrm{PH}$ and ion concentrations in blood plasma, uterine fluid and epithelial cells during eggshell mineralisation[5]

\begin{tabular}{lcccc}
\hline & Blood plasma & Epithelial cells & \multicolumn{2}{c}{ Uterine fluid } \\
\cline { 3 - 5 } & & & $\mathbf{8} \mathbf{~ h ~ P O}$ & $\mathbf{1 8 ~ \mathbf { ~ P O }}$ \\
\hline lons & {$[\mathrm{mM}]$} & {$[\mathbf{m M}]$} & {$[\mathbf{m M}]$} & {$[\mathbf{m M}]$} \\
\hline $\mathrm{Ca}^{2+}$ & 1.2 & $<0.0002$ & 6 & 10 \\
\hline $\mathrm{Na}^{+}$ & 140 & 12 & 144 & 80 \\
\hline $\mathrm{K}^{+}$ & 4 & 139 & 12 & 60 \\
\hline $\mathrm{HCO}_{3}^{-}$ & 23 & 12 & 60 & 110 \\
\hline $\mathrm{pH}^{-}$ & 7.4 & $7.0-7.4$ & 7.6 & 7.1 \\
\hline $\mathrm{Cl}^{-}$ & 130 & 4 & 71 & 45 \\
\hline
\end{tabular}

The eggshell precursors are secreted in the uterine fluid where the eggshell mineralization daily takes place from 10 hours to 22 hours post ovulation (yolk entry in the oviduct). PO: post ovulation. uterine calbindin levels and $\mathrm{Ca}^{2+}$ flux [11,13,14]. This protein could also take part in maintaining low intracellular $\mathrm{Ca}^{2+}$ to avoid cell death as observed in other species and tissues [15]. $\mathrm{Ca}^{2+}$ secretion from epithelial cells to the uterine fluid is active involving a $\mathrm{Ca}^{2+}$ ATPase, the activity of which varies with the stage of eggshell calcification [4,7]. A recent study [16] identified and localized the plasma membrane $\mathrm{Ca}^{2+}$ ATPase isoform 4 (PMCA4) in the apical membrane of epithelial cells of king quail. The disruption of sodium $\left(\mathrm{Na}^{+}\right)$reabsorption by specific inhibitors in perfused uterus or in vitro reduced $\mathrm{Ca}^{2+}$ secretion by $50 \%[9,17]$, revealing a strong relationship between $\mathrm{Na}^{+}$and $\mathrm{Ca}^{2+}$ transfers and therefore the putative presence of $\mathrm{Na}^{+} / \mathrm{Ca}^{2+}$ exchangers in uterine cells. The $\mathrm{Na}^{+} / \mathrm{K}^{+}$ATPase responsible for $\mathrm{Na}^{+}$re-absorption in the plasma membrane is characterised and is upregulated during the period of shell calcification [18].

The second essential component of eggshell mineralisation is carbonate. Blood carbon dioxide $\left(\mathrm{CO}_{2}\right)$ is provided in cells by passive diffusion through the plasma membrane $[2,19]$. In the uterine tubular gland cells, a family of key enzymes, the carbonic anhydrases (CA) [6] catalyses the hydration of $\mathrm{CO}_{2}$ to $\mathrm{HCO}_{3}^{-}$as confirmed by inhibition of $\mathrm{HCO}_{3}^{-}$production and secretion by acetazolamide, a CA inhibitor [9]. Chloride $\left(\mathrm{Cl}^{-}\right)$is absorbed by the uterus and any perturbation of $\mathrm{Na}^{+}$flux by ouabain [9] reverses both the $\mathrm{Na}^{+}$and $\mathrm{Cl}^{-}$fluxes, but reduces also $\mathrm{HCO}_{3}^{-}$secretion suggesting that its transfer is dependent on $\mathrm{Cl}^{-}$via a $\mathrm{Cl}^{-} / \mathrm{HCO}_{3}^{-}$exchanger which has not been identified. Finally, the production of $\mathrm{HCO}_{3}^{-}$in tubular gland cells and of $\mathrm{CO}_{3}^{2-}$ in the uterine fluid generates high levels of protons $\left(\mathrm{H}^{+}\right)$ions. The concomitant decrease in uterine and plasma $\mathrm{pH}$ during calcification reflects the reabsorption of $\mathrm{H}^{+}$[5].

Only a few genes and related proteins involved in uterine ion transfer have been identified to date. Our objective therefore was to use the recent information issuing from the chicken genome sequencing [20] and subsequent enrichment in the chicken gene/protein databases to identify uterine ion transport proteins. Use of a recent transcriptomic study revealing uterine genes related to eggshell calcification [21] and of the analogies with transporters previously described in mammalian tissues transferring large quantities of ions (intestine, kidney, pancreas) allows the identification of putative genes encoding proteins involved in uterine trans-epithelial ion transports. Confirmation of their presence in birds and evaluation of their involvement have been analysed by comparing gene expression in the uterus compared to the magnum (the oviduct segment responsible for the synthesis and secretion of egg white proteins) and the duodenum $\left(\mathrm{Ca}^{2+}\right.$ uptake and neutralization of stomach acid), where both $\mathrm{Ca}^{2+}$ and $\mathrm{HCO}_{3}^{-}$trans-epithelial 


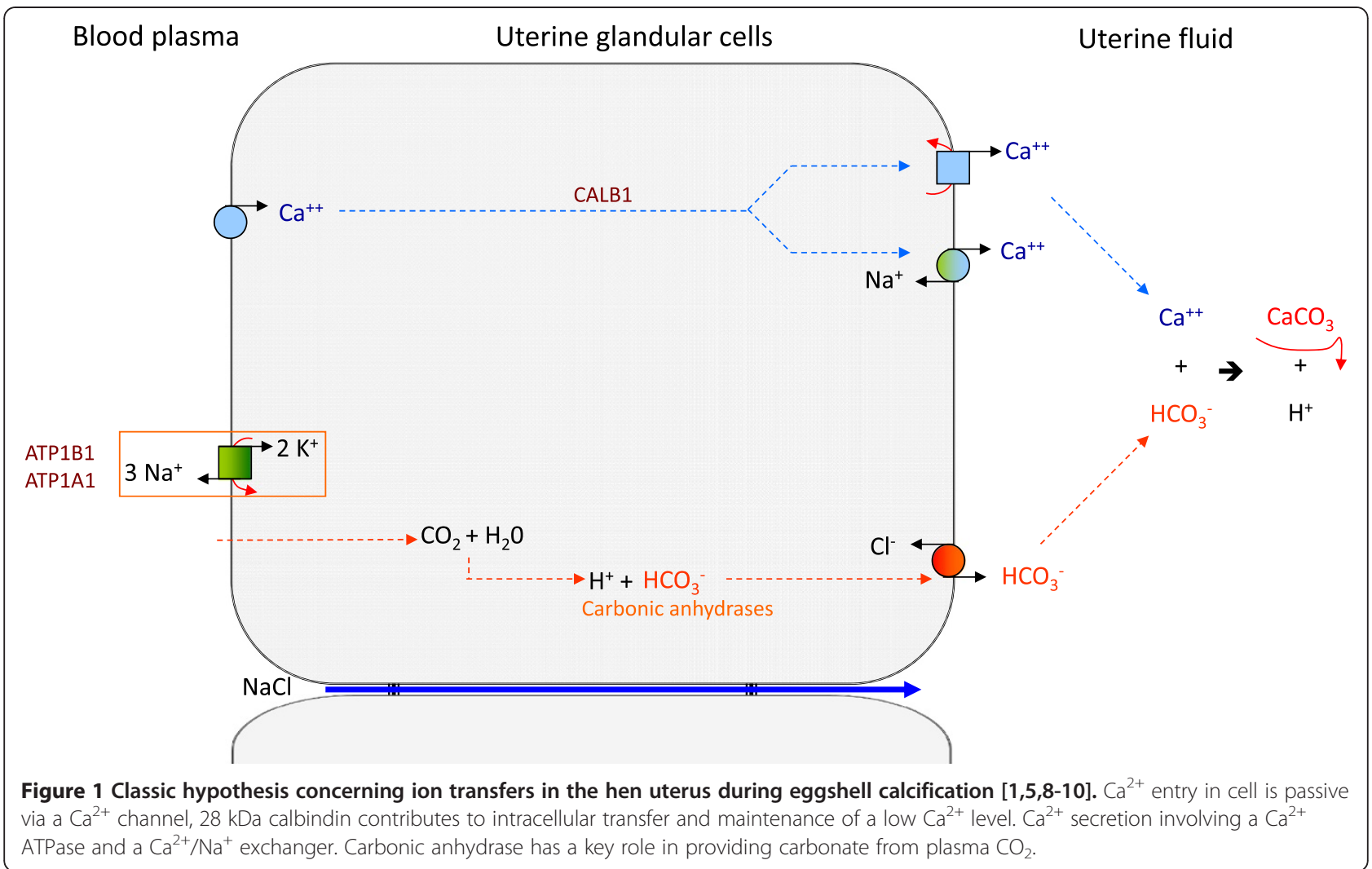

transfers are respectively low and high. The magnum and the uterus secrete a large amount of water, $\mathrm{Na}^{+}$and $\mathrm{Cl}^{-}$during the phase of hydration of egg albumen which takes place before the active phase of eggshell formation in the uterus [5,22]. By contrast, the duodenum is the proximal region of the intestine with a high capacity for $\mathrm{Ca}^{2+}$ absorption [23] and secretes a large amount of $\mathrm{HCO}_{3}^{-}$for neutralization of gastric acidity $[24,25]$. An additional experimental approach was the comparison of gene expression in the uterus isolated from hens at the stage of eggshell formation, to those for which eggshell formation was suppressed by premature egg expulsion. We identified a large number of genes coding for ion transport and propose a general model describing the putative contribution and localisation of the ion transporters in the tubular gland cell of the hen's uterus.

\section{Results}

\section{Identification of uterine ion transporters}

The first step of this work was to establish a list of ion transporters potentially involved in supplying eggshell minerals. The ion transfer model established in the Gallus gallus uterus (Figure 1) using physiological data $[5,8,9]$ was used to produce a first list of genes encoding ionic transporter proteins. This approach was completed by using a recent transcriptomic study revealing genes overexpressed in the uterus (shell formation) compared to the magnum (egg white protein secretion) [21] and analogies with transporters previously described in mammalian tissues at the intestinal and kidney level $[24,26]$. A list of 37 genes was therefore selected as candidates possibly involved in uterine trans-epithelial ion transfers (Table 2). To facilitate identification of candidates in the manuscript, we have only used the gene symbol for describing both genes and proteins.

\section{Uterine expression of the $\mathbf{3 7}$ genes encoding ion transporters}

The mRNA expression of 37 transporters was analysed by RT-PCR in the uterus, and three other ion secreting or absorbing epithelia (magnum, duodenum and kidney) and in muscle where no trans-epithelial ion transfer occurs (Additional file 1: Table 1). Amongst these 37 genes, mRNA expression was observed in the uterus for 34 genes. Three genes (the endoplasmic $\mathrm{Ca}^{2+}$ pump type 1(ATP2A1), two exchangers $\mathrm{Na}^{+}$dependent (SLC4A8) or independent (SLC4A9) $\mathrm{Cl}^{-} / \mathrm{HCO}_{3}^{-}$were not expressed in the uterus and were not further studied.

A large majority of these 34 genes were also revealed in the duodenum. Conversely, SLC4A8 was expressed only in duodenum. Four genes were revealed only in the uterus and were not present in the magnum (TRPV6, CALB1, SCNN1B and SLC26A9) or in muscle (CALB1, SCNN1B, SLC4A10 and CLCN2). The 34 genes revealed 
Table 2 Function of genes potentially involved in the ion transfer for supplying eggshell mineral precursors in hen uterus

\begin{tabular}{|c|c|c|c|}
\hline Name & Gene symbol & Functional data & Transfer type \\
\hline $\begin{array}{l}\text { Transient receptor potential cation channel } \\
\text { subfamily } \vee \text { member } 6\end{array}$ & TRPV6 & & $\mathrm{Ca}^{2+}$ channel (plasma membrane) \\
\hline Calbindin $28 \mathrm{~K}$ & CALB1 & {$[11,14,28]$} & $\mathrm{Ca}^{2+}$ intracellular transporter (intracellular) \\
\hline Endoplasmic reticulum calcium ATPase 1 & ATP2A1 & & $\mathrm{Ca}^{2+}$ ATPases (endoplasmic \& plasma membrane) \\
\hline Endoplasmic reticulum calcium ATPase 2 & ATP2A2 & & \\
\hline Endoplasmic reticulum calcium ATPase 3) & ATP2A3 & & \\
\hline IP3 receptor1 & ITPR1 & & $\mathrm{Ca}^{2+}$ channels (endoplasmic membrane) \\
\hline IP3 receptor2 & ITPR2 & & \\
\hline IP3 receptor3 & ITPR3 & & \\
\hline Ryanodine receptor 1 & RYR1 & & $\mathrm{Ca}^{2+}$ channel (endoplasmic membrane) \\
\hline $\begin{array}{l}\text { Plasma membrane calcium-transporting } \\
\text { ATPase } 1 \text { (PMCA1) }\end{array}$ & ATP2B1 & & $\mathrm{Ca}^{2+} / \mathrm{H}^{+}$exchanger (plasma membrane) \\
\hline $\begin{array}{l}\text { Plasma membrane calcium-transporting } \\
\text { ATPase } 2 \text { (PMCA2) }\end{array}$ & ATP2B2 & & \\
\hline $\begin{array}{l}\text { Plasma membrane calcium-transporting } \\
\text { ATPase } 4 \text { (PMCA4) }\end{array}$ & ATP2B4 & {$[16]$} & \\
\hline Sodium/calcium exchanger 1 & SLC8A1 & & $\mathrm{Na}^{+} / \mathrm{Ca}^{2+}$ exchanger (plasma membrane) \\
\hline Sodium/calcium exchanger 3 & SLC8A3 & & \\
\hline $\begin{array}{l}\text { Amiloride-sensitive sodium channel subunit } \\
\text { alpha }\end{array}$ & SCNN1A & {$[31]$} & $\mathrm{Na}^{+}$channels (plasma membrane) \\
\hline $\begin{array}{l}\text { Amiloride-sensitive sodium channel subunit } \\
\text { beta }\end{array}$ & SCNN1B & [31] & \\
\hline $\begin{array}{l}\text { Amiloride-sensitive sodium channel subunit } \\
\text { gamma }\end{array}$ & SCNN1G & [31] & \\
\hline $\begin{array}{l}\text { Sodium/potassium-transporting ATPase subunit } \\
\text { alpha-1 }\end{array}$ & ATP1A1 & [18] & $\mathrm{Na}^{+} / \mathrm{K}^{+}$exchanger (plasma membrane) \\
\hline $\begin{array}{l}\text { Sodium/potassium-transporting ATPase subunit } \\
\text { beta-1 }\end{array}$ & ATP1B1 & {$[18]$} & \\
\hline Solute carrier family 4 member 4 & SLC4A4 & & $\mathrm{Na}^{+} / \mathrm{HCO}_{3}^{-}$co-transporters (plasma membrane) \\
\hline Solute carrier family 4 member 5 & SLC4A5 & & \\
\hline Solute carrier family 4 member 7 & SLC4A7 & & \\
\hline Solute carrier family 4 member 10 & SLC4A10 & & \\
\hline Inward rectifier potassium channel 2 & KCNJ2 & & Inward rectifiers $\mathrm{K}^{+}$channels (plasma membrane) \\
\hline Inward rectifier potassium channel 5 & KCNJ15 & & \\
\hline Inward rectifier potassium channel 16 & KCNJ16 & & \\
\hline $\begin{array}{l}\text { Calcium-activated potassium channel subunit } \\
\text { alpha-1 }\end{array}$ & KCNMA1 & & $\mathrm{K}^{+}$channel (plasma membrane) \\
\hline Carbonic anhydrase 2 & CA2 & [6] & Catalyse $\mathrm{HCO}_{3}^{-}$formation (plasma membrane) \\
\hline Carbonic anhydrase 4 & CA4 & & \\
\hline Carbonic anhydrase 7 & CA7 & & \\
\hline Solute carrier family 4 member 8 & SLC4A8 & & $\mathrm{HCO}_{3}^{-} / \mathrm{Cl}^{-}$exchangers (plasma membrane) \\
\hline Solute carrier family 4 member 9 & SLC4A9 & & \\
\hline Solute carrier family 26 member 9 & SLC26A9 & & \\
\hline $\begin{array}{l}\text { Vacuolar H ATPase B subunit osteoclast } \\
\text { isozyme }\end{array}$ & ATP6V1B2 & & $\mathrm{H}^{+}$pump (organelles and plasma membrane \\
\hline $\begin{array}{l}\text { Cystic fibrosis transmembrane conductance } \\
\text { regulator }\end{array}$ & CFTR & & $\mathrm{Cl}^{-}$channel (plasma membrane) \\
\hline Chloride channel protein 2 & CLCN2 & & $\mathrm{Cl}^{-}$channel (plasma membrane) \\
\hline $\mathrm{H}(+) / \mathrm{Cl}(-)$ exchange transporter 5 & CLCN5 & & $\mathrm{Cl}^{-} / \mathrm{H}^{+}$exchanger (plasma membrane) \\
\hline
\end{tabular}


in the uterus are candidates for supplying ions in the uterus.

\section{Comparative expression of ion transfer genes between uterus and other secreting tissues}

The expression of the 34 genes encoding proteins potentially involved in uterine ion transfer were quantitatively evaluated by comparing their gene expression in the uterus to those of two other tissues (magnum, duodenum) where $\mathrm{Ca}^{2+}$ and $\mathrm{HCO}_{3}^{-}$trans-epithelial transport are at low and high levels, respectively. After normalisation, the fold changes in gene expression between uterus vs magnum and uterus vs duodenum was statistically analysed (Figure 2).

Amongst the 34 comparisons of gene expression between the uterus and the magnum, only one gene (the ryanodine receptor 1 ) was not differentially expressed. The 33 other genes showed higher levels of gene expression in the uterus than in the magnum (fold change of Ut/Ma up to $12 \mathrm{ln}$ ). Amongst these 33 genes, 16 genes (underlined in the following list) are not differentially expressed between uterus and duodenum suggesting they are equally important in both tissues able to absorb or secrete large amounts of $\mathrm{Ca}^{2+}$ and $\mathrm{HCO}_{3}^{-}$. These 33 gene candidates suspected to be involved in uterine ionic transfer corresponded to:

(1) $\mathrm{Ca}^{2+}$ transfer: TRPV $\mathrm{Ca}^{2 \pm}$ channel (TRPV6), calbindin $28 \mathrm{kDa}$ (CALB1), endoplasmic $\mathrm{Ca}^{2 \pm}$ pump type 2 and 3 (ATP2A2, 3), inositol trisphosphate receptor type 1, 2, 3 (ITPR1, 2, 3), $\mathrm{Ca}^{2 \pm}$ pumps PMCA type 1,2 and 4

(ATP2B1, 2, 4) and $\mathrm{Ca}^{2 \pm} / \mathrm{Na}^{ \pm}$exchanger type 1,3 (SLC8A1, 3).

(2) $\mathrm{Na}^{+}$transfer: amiloride-sensitive $\mathrm{Na}^{+}$channel subunit $\alpha, \beta$, and $\gamma(\mathrm{SCNN} 1 \mathrm{~A}, \mathrm{~B}, \mathrm{G}), \mathrm{Na}^{ \pm} / \mathrm{K}^{ \pm}$ transporting ATPase subunit $\alpha$ and $\beta$ (ATP1A1, B1), $\mathrm{Ca}^{2 \pm} / \mathrm{Na}^{ \pm}$exchanger type 1 and 3 (SLC8A1, 3), several $\mathrm{Na}^{ \pm} / \mathrm{HCO}_{3}^{-}$co-transporters (SLC4A4, 5, 7, 10).

(3) $\mathrm{K}^{+}$transfer: $\mathrm{Na}^{ \pm} / \mathrm{K}^{ \pm}$transporting ATPase subunit $\alpha$ and $\beta$ (ATP1A1, B1) and several $\mathrm{K}^{ \pm}$channels (KCNJ2, 15, 16, KCNMA1).

(4) $\mathrm{HCO}_{3}^{-}$production and transfer: CAs type 2, 4, 7, (CA2, 4, 7), an $\mathrm{HCO}_{3}^{-} / \mathrm{Cl}^{-}$exchanger (SLC26A9), and several $\mathrm{Na}^{ \pm} / \mathrm{HCO}_{3}^{-}$co-transporters (SLC4A4, 5, 7, 10).

(5) $\mathrm{H}^{+}$transfer: $\mathrm{VH}^{ \pm}$ATPase pump subunit B (ATP6V1B2), and $\mathrm{Cl}^{-} / \mathrm{H}^{+}$exchanger (CLCN5).

(6) $\mathrm{Cl}^{-}$transfer: CFTR channel (CFTR), $\mathrm{Cl}^{-}$channel protein 2 (CLCN2), an $\mathrm{HCO}_{3}^{-} / \mathrm{Cl}^{-}$ exchanger (SLC26A9) and a $\mathrm{Cl}^{-} / \mathrm{H}^{+}$exchanger (CLCN5).

Fourteen genes amongst the 33 were overexpressed in the uterus compared with the duodenum. This overexpression of transporters in the uterus relative to the

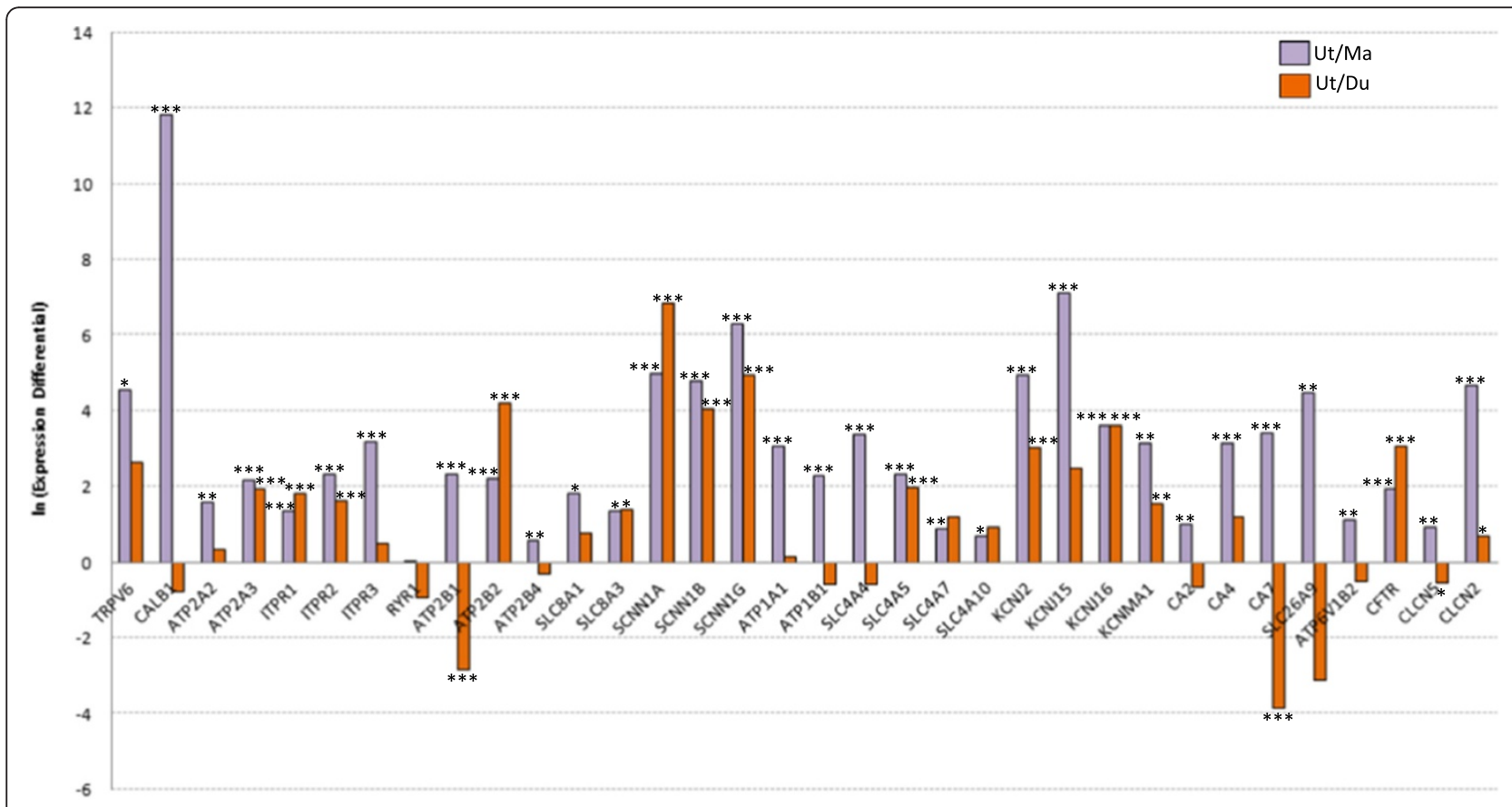

Figure 2 Relative expression of genes coding ion transporters in chicken uterus compared to magnum or duodenum. Gene expression of ion transporters for eggshell mineralisation were quantitatively evaluated by qRT-PCR in the uterus (eggshell formation) and compared to those of magnum and duodenum where $\mathrm{Ca}^{2+}$ and $\mathrm{HCO}_{3}^{-}$trans-epithelial transport are at low and high levels, respectively. 
duodenum is indicative of genes whose function is more uterine specific. They corresponded to:

(1) $\mathrm{Ca}^{2+}$ transfer: endoplasmic $\mathrm{Ca}^{2+}$ pump type 3 (ATP2A3), inositol trisphosphate receptors (ITPR1, 2), $\mathrm{Ca}^{2+}$ pumps PMCA2 (ATP2B2) and $\mathrm{Ca}^{2+} / \mathrm{Na}^{+}$exchanger type 3 (SLC8A3).

(2) $\mathrm{Na}^{+}$transfer: amiloride-sensitive $\mathrm{Na}^{+}$channel subunit $\alpha, \beta$, and $\gamma(\mathrm{SCNN} 1 \mathrm{~A}, \mathrm{~B}, \mathrm{G}), \mathrm{Ca}^{2+} / \mathrm{Na}^{+}$ exchanger type 3 (SLC8A3), $\mathrm{Na}^{+} / \mathrm{HCO}_{3}^{-}$ co-transporters (SLC4A5).

(3) $\mathrm{K}^{+}$transfer: several $\mathrm{K}^{+}$channels (KCNJ2, 16 and KCNMA1).

(4) $\mathrm{HCO}_{3}^{-}$production and transfer: $\mathrm{Na}^{+} / \mathrm{HCO}_{3}^{-}$ co-transporters (SLC4A5).

(5) $\mathrm{Cl}^{-}$transfer: $\mathrm{Cl}^{-}$channel protein 2 (CLCN2) and CFTR channel (CFTR).

Three genes are underexpressed in the uterus compared with the duodenum suggesting that their function is more specific to the duodenum:

(1) $\mathrm{Ca}^{2+}$ transfer: $\mathrm{Ca}^{2+}$ pumps PMCA1 (ATP2B1).

(2) $\mathrm{HCO}_{3}^{-}$production and transfer: CA type 7 (CA7).

(3) $\mathrm{H}^{+}$transfer and (4) $\mathrm{Cl}^{-}$transfer: $\mathrm{H}^{+} / \mathrm{Cl}^{-}$ exchanger (CLCN5).

\section{Comparative expression of genes in the presence or absence of eggshell formation}

This model was explored to reveal regulation of gene expression associated with the process of shell formation and to discern some of the ionic transport proteins more likely to be involved in supplying shell mineral precursors. We compared expression of these genes in the uterus when calcification takes place or after its suppression due to premature expulsion of the eggs for 3-4 consecutive days. The early egg expulsion eliminates the $\mathrm{Ca}^{2+}$ and $\mathrm{HCO}_{3}^{-}$requirement for shell formation, and eliminates the mechanical stimulation of the uterine wall due to the presence of the egg, which is known to upregulate expression of certain genes. Fold changes in gene expression between the calcifying or inactive uterus are presented in Figure 3.

Twelve genes amongst 33 were overexpressed in the presence of eggshell calcification compared to hens in which shell formation had been suppressed (67 fold change):

(1) $\mathrm{Ca}^{+2+}$ transfer: $28 \mathrm{kDa}$ calbindin (CALB1), endoplasmic $\mathrm{Ca}^{2+}$ pump type 3 (ATP2A3), and $\mathrm{Ca}^{2+}$ pumps PMCA2 (ATP2B1, 2).

(2) $\mathrm{Na}^{+}$transfer: amiloride-sensitive $\mathrm{Na}^{+}$channel subunit $\gamma(\mathrm{SCNN1G})$ and $\mathrm{Na}^{+} / \mathrm{K}^{+}$transporting ATPase subunit $\alpha$ (ATP1A1).

(3) $\mathrm{K}^{+}$transfer: $\mathrm{Na}^{+} / \mathrm{K}^{+}$transporting ATPase subunit $\alpha$ (ATP1A1) and the $\mathrm{K}^{+}$channels (KCNJ2, KCNJ15 and KCNMA1).

(4) $\mathrm{HCO}_{3}^{-}$production and transfer: carbonic anhydrase CA type 2 (CA2), an $\mathrm{HCO}_{3}^{-} / \mathrm{Cl}^{-}$exchanger (SLC26A9).

(5) $\mathrm{Cl}^{-}$transfer: the $\mathrm{Cl}^{-}$channel (CFTR) and an $\mathrm{HCO}_{3}^{-} / \mathrm{Cl}^{-}$exchanger (SLC26A9).

In contrast, 2 genes corresponding to a $\mathrm{Ca}^{2+} / \mathrm{H}^{+}$ exchanger (ATP2B4) and to a $\mathrm{Na}^{+} / \mathrm{HCO}_{3}^{-}$co-transporter (SLC4A7) showed an underexpression when eggshell calcification takes place.

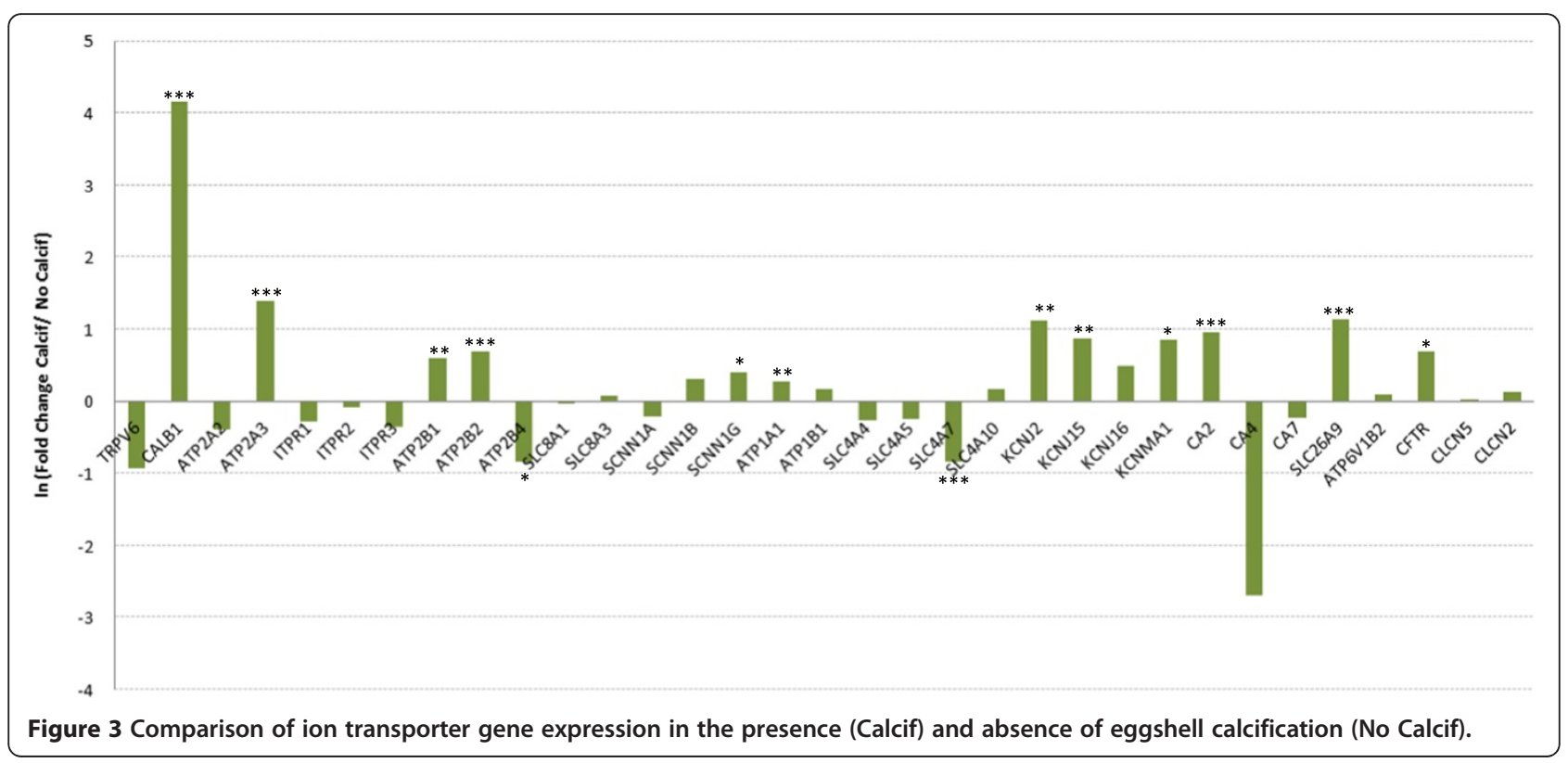


Nineteen of the 33 uterine genes did not show any fold change between these two physiological conditions:

(1) $\mathrm{Ca}^{2+}$ transfer: TRPV $\mathrm{Ca}^{2+}$ channel (TRPV6), endoplasmic $\mathrm{Ca}^{2+}$ pump type 2 (ATP2A2), inositol trisphosphate receptors (ITPR1, 2, 3), and $\mathrm{Ca}^{2+} / \mathrm{Na}^{+}$exchanger type 1 and 3 (SLC8A1, 3).

(2) $\mathrm{Na}^{+}$transfer: amiloride-sensitive $\mathrm{Na}^{+}$channel subunit $\alpha$ and $\gamma(\mathrm{SCNN} 1 \mathrm{~A}, \mathrm{~B}), \mathrm{Na}^{+} / \mathrm{K}^{+}$transporting ATPase subunit $\beta$ (ATP1B1), $\mathrm{Ca}^{2+} / \mathrm{Na}^{+}$ exchanger type 1 and 3 (SLC8A1, 3), $\mathrm{Na}^{+} / \mathrm{HCO}_{3}^{-}$ co-transporters (SLC4A4, 5, 10).

(3) $\mathrm{K}^{+}$transfer: $\mathrm{Na}^{+} / \mathrm{K}^{+}$transporting ATPase subunit $\beta$ (ATP1B1) and a $\mathrm{K}^{+}$channel (KCNJ16).

(4) $\mathrm{HCO}_{3}^{-}$production and transfer: $\mathrm{CA}$ type 4,7 (CA4, 7), several $\mathrm{Na}^{+} / \mathrm{HCO}_{3}^{-}$co-transporters (SLC4A4, 5, 10).

(5) $\mathrm{Cl}^{-}$transfer: $\mathrm{Cl}^{-}$channel protein 2 (CLCN2) and $\mathrm{H}^{+} / \mathrm{Cl}^{-}$exchanger (CLCN5).

(6) $\mathrm{H}^{+}$transfer: $\mathrm{VH}^{+}$ATPase pump subunit B (ATP6V1B2) and $\mathrm{H}^{+} / \mathrm{Cl}^{-}$exchanger (CLCN5).

\section{Discussion}

Eggshell calcification in the avian uterus is one of the fastest mineralisation processes in the living world. The $\mathrm{Ca}^{2+}$ metabolism is intense in Gallus gallus hens which export a large amount of $\mathrm{Ca}^{2+}$ (2 g daily) and consequently there are numerous physiological adaptations to support this function [1,27-30]. In fact, an eggproducing hen shows a specific appetite for $\mathrm{Ca}^{2+}$ a few hours before shell calcification is initiated and its capacity to absorb $\mathrm{Ca}^{2+}$ in the intestine increases by 6 -fold due to large stimulation of the active metabolite of vitamin $\mathrm{D}$ at the kidney level. The uterus acquires the capacity to transfer a great quantity of $\mathrm{Ca}^{2+}$ and $\mathrm{HCO}_{3}^{-}$for supplying mineral precursors of the eggshell during less than 14 hours. This model is therefore particularly relevant to explore the mechanisms of mineral transport needed for the extracellular biomineralisation of the eggshell. In this study, we focused on intracellular ionic transporters and did not explore the proteins involved in their regulation. This process has been the object of many physiological and pharmacological works as reviewed by Nys [1] and Bar [30]. However, the molecular identification of ionic transporters remains incomplete in the uterus. Genome sequencing in human and other mammalian species has contributed to the molecular identification of genes and related proteins involved in ionic trans-epithelial transfer in the intestine and kidneys [24,26]. By using this literature and data provided by a recent high throughput analysis of chicken uterine genes related to eggshell calcification [21], we identified 37 putative genes encoding ion trans-epithelial transporters and tested their involvement in providing mineral precursors in the hen's uterus. Analysis of their expression by RT-PCR, showed that 34 of these genes were expressed at the uterine level. In order to study their involvement in providing both $\mathrm{Ca}^{2+}$ and $\mathrm{HCO}_{3}^{-}$for eggshell formation, the expression of these 34 genes in the uterus was quantified by qRT-PCR and compared with two other epithelia (magnum and duodenum) where $\mathrm{Ca}^{2+}$ and $\mathrm{HCO}_{3}^{-}$transfers are respectively low and high. In addition, the expression of these genes was compared in the uterus during two situations: during eggshell calcification and when $\mathrm{Ca}^{2+}$ and $\mathrm{HCO}_{3}^{-}$secretions were suppressed due to premature egg expulsion. These approaches allowed the identification of numerous transporting proteins providing minerals for shell formation in the hen's uterus.

\section{$\mathrm{Ca}^{2+}$ transfer}

$\mathrm{Ca}^{2+}$ is not stored in the uterus before eggshell calcification but comes from blood plasma by trans-epithelial transport. This $\mathrm{Ca}^{2+}$ export is extremely rapid during calcification and corresponds to a consumption of the total plasmatic $\mathrm{Ca}^{2+}$ pool every $12 \mathrm{~min}$. Studies of $\mathrm{Ca}^{2+}$ transfer in vivo using perfusion of uterus [8,9] and in vitro exploring the effects of inhibitors of ion ATPases or carbonic anhydrase [10,31], and ionic analysis of uterine fluid during eggshell formation [5], made it possible to build a first model of $\mathrm{Ca}^{2+}$ transfer in the uterus (Figure 1): $\mathrm{Ca}^{2+}, \mathrm{HCO}_{3}^{-}$secretion and $\mathrm{Na}^{+}$reabsorption was considered to occur against their electrochemical gradient, to involve active intracellular transfer as shown by specific inhibitors [8-10] and to occur in the uterine glandular cells as revealed by immunohistochemistry of transport proteins [32]. Trans-epithelial transfer of $\mathrm{Ca}^{2+}$ occurs in three steps as observed in all transporting epithelia: $\mathrm{Ca}^{2+}$ influx through a downhill gradient, an intracellular $\mathrm{Ca}^{2+}$ transport involving calbindin $28 \mathrm{kDa}$ protein [33] and active output into the lumen through a $\mathrm{Ca}^{2+}$ pump [4]. The high plasma $\mathrm{Ca}^{2+}$ concentration (1.2 $\mathrm{mM}$ free $\mathrm{Ca}^{2+}$ ) relative to the uterine cell interior $\left(10^{-4} \mathrm{mM}\right.$ free $\mathrm{Ca}^{2+}$ ) (Table 1 ) suggests that the $\mathrm{Ca}^{2+}$ entry into cells passively occurs via $\mathrm{Ca}^{2+}$ selective channels present in the basolateral plasma membrane. In other tissues, such as intestine, kidney and plasma, TRPVs 5, 6 (Transient Receptor Potential Vanilloid) are epithelial channels that represent the principal pathway for $\mathrm{Ca}^{2+}$ uptake into the cell [26,34]. Our study showed that in Gallus gallus, only one gene [NCBI Gene ID: 418307; Swiss-Prot: TRPV6] is present. This channel is significantly overexpressed in the uterus compared with the magnum, where $\mathrm{Ca}^{2+}$ transfer is low. Its uterine expression is similar to that of the duodenum where $\mathrm{Ca}^{2+}$ absorption is also large. Cellular $\mathrm{Ca}^{2+}$ influx might use a similar $\mathrm{Ca}^{2+}$ channel, TRPV6, at the intestinal and uterine level but their localisation is hypothesized to differ 
according to the site of $\mathrm{Ca}^{2+}$ influx, being located in the basal membrane in the uterus but in the apical membrane in the intestine. The uterine expression of TRPV6 is not however modified according to whether calcification takes place. The presence of other $\mathrm{Ca}^{2+}$ channels cannot be ruled out as additional putative candidates. A recent transcriptomic study in our laboratory comparing uterine gene expression in hens with or without shell calcification revealed the presence of high expression of TRPC1, TRPP, TRPM7, TRPML1 and ORAI 1 (unpublished data, Brionne A, Nys Y and Gautron J).

An intracellular $\mathrm{Ca}^{2+}$ buffer is crucial to keep the free cytosolic $\mathrm{Ca}^{2+}$ concentration below toxic levels. Following $\mathrm{Ca}^{2+}$ entry into the uterine glandular cell, several systems could contribute to intracellular transport of $\mathrm{Ca}^{2+}$, while maintaining the low but essential free $\mathrm{Ca}^{2+}$ concentration for survival of the cell. In certain tissues, calbindin proteins, $9 \mathrm{kDa}$ and $28 \mathrm{kDa}$ in mammals [15] or $28 \mathrm{kDa}$ in birds [3,35], are present at high cytosolic concentration and possess high $\mathrm{Ca}^{2+}$ binding capacity. Direct correlation has been demonstrated between their mucosal concentration and the efficiency of $\mathrm{Ca}^{2+}$ transfer in intestine and uterus under numerous experimental conditions $[26,28,30]$. It is generally accepted that calbindins facilitate the diffusion of intracellular $\mathrm{Ca}^{2+}$ and serve as a $\mathrm{Ca}^{2+}$ buffer needed for cell protection against $\mathrm{Ca}^{2+}$ stress and accompanying apoptotic cellular degradation that is induced by a high intracellular $\mathrm{Ca}^{2+}$ concentration $[15,36,37]$. In our study, we observed an elevated expression of calbindin $28 \mathrm{kDa}$ in the uterus during calcification of an eggshell compared to the magnum (Figure 2) and compared to the uterus with no shell in formation (fold difference in expression: 67) in agreement with previous studies $[11,14,28]$. This uterine calbindin $28 \mathrm{kDa}$ is therefore associated with intracellular $\mathrm{Ca}^{2+}$ transport from the basal membrane of the glandular cells to the apical membrane where $\mathrm{Ca}^{2+}$ is extruded into the uterine fluid.

An alternative system in mammals to maintain a low intracellular $\mathrm{Ca}^{2+}$ concentration relies on the endoplasmic reticulum which contributes to $\mathrm{Ca}^{2+}$ homeostasis through its capacity for $\mathrm{Ca}^{2+}$ uptake and storage [38,39]. The endoplasmic reticulum $\mathrm{Ca}^{2+}$ ATPases (ATP2A1, 2, 3) play an active role in $\mathrm{Ca}^{2+}$ uptake by this organelle (reaching 10 to $100 \mathrm{mM}$ free $\mathrm{Ca}^{2+}$ ), while maintaining the cytoplasmic concentration at low concentrations of $10^{-4} \mathrm{mM}$ free $\mathrm{Ca}^{2+}$. Amongst the three isoenzymes (Table 2), only ATP2A2 and ATP2A3 were overexpressed in the uterus compared to the magnum. The absence of ATP2A1 expression fits with its predominant localisation in mammalian muscle in contrast to ATP2A2 and ATP2A3 which are expressed in numerous tissues [40]. The overexpression of ATP2A3 in the uterus compared to duodenum suggests a more crucial role of this transporter, the regulation of which remained to be explored.
The inositol 1, 4, 5-trisphosphate receptors (ITPR) are intracellular $\mathrm{Ca}^{2+}$ channels, localised mainly in the endoplasmic reticulum $[41,42]$ and allowing the release of $\mathrm{Ca}^{2+}$ from this organelle. The three isoforms (ITPR1, 2 3) were overexpressed in the uterus compared to the magnum but were not modified when comparing the presence or absence of calcification. The higher expression of ITPR1 and ITPR 2 in the uterus compared to the duodenum supports our hypothesis concerning their contribution to the regulation of intra-cellular $\mathrm{Ca}^{2+}$. The ryanodine receptors which are involved in muscle excitationcontraction coupling in mammalian tissues [38] are alternative channels for $\mathrm{Ca}^{2+}$ release from the endoplasmic reticulum. RYR1 expression was revealed in the uterus, but there was no difference between the uterus, magnum or duodenum, suggesting a weak involvement in endoplasmic reticulum $\mathrm{Ca}^{2+}$ release. In conclusion, these observations of high expression of genes encoding ATP2A pumps and ITPR $\mathrm{Ca}^{2+}$ channels involved in $\mathrm{Ca}^{2+}$ uptake and release in endoplasmic reticulum suggest the involvement of this organelle in intracellular $\mathrm{Ca}^{2+}$ buffering in uterine glandular cells.

The last step of uterine $\mathrm{Ca}^{2+}$ trans-epithelial transport is output from the glandular cells, which occurs against a concentration gradient. $\mathrm{Ca}^{2+}$ secretion towards the uterine fluid occurs via an active process, involving the $\mathrm{Ca}^{2+}$ ATPase $[7,32,43]$. This has recently been associated with the PMCA4 (plasma membrane ATPase $\mathrm{Ca}^{2+}$ ) [16]. Four isoenzymes (ATP2B1, B2, B3 and B4) of PMCAs pumps are identified in mammals [44]. Only three (ATP2B1, B2, B4) are conserved in birds. Each of these were overexpressed in the uterus compared to the magnum (Figure 2). ATP2B2 was also overexpressed in the uterus compared to the duodenum, and in presence of the eggshell mineralisation (Figure 3 ) suggesting a more active role in $\mathrm{Ca}^{2+}$ secretion at the uterine level. In contrast, $\mathrm{ATP} 2 \mathrm{~B} 1$ and $\mathrm{ATP} 2 \mathrm{~B} 4$ were underexpressed in the uterus compared to duodenum and for ATP2B4 in presence of shell formation. In mammals, it is ATP2B1 which plays a more important role in intestinal $\mathrm{Ca}^{2+} \mathrm{ab}-$ sorption $[26,45]$. In other bird species, Parker et al. [16] localized the plasma membrane $\mathrm{Ca}^{2+}$-transporting ATPase 4 (ATP2B4) in the apical membrane of uterine epithelial cells but did not explore the presence of ATP2B2 and its differential expression during calcification. In human osteoblasts, the isoforms 1 and 2 take part in the $\mathrm{Ca}^{2+}$ supply necessary for bone mineralisation whereas the isoform 4 is not detected [46].

It was observed thirty years ago that the inhibition of $\mathrm{Na}^{+}$transfer by $\mathrm{Na}^{+} / \mathrm{K}^{+}$ATPase inhibitors considerably reduced $\mathrm{Ca}^{2+}$ secretion into the uterine lumen $[9,17]$, showing a coupling between uterine $\mathrm{Ca}^{2+}$ secretion and $\mathrm{Na}^{+}$re-absorption. The uterine absorption of $\mathrm{Na}^{+}$is revealed by the decreased $\mathrm{Na}^{+}$concentrations in the 
uterine fluid observed between the early stage of shell calcification and the end of calcification (Table 1). These observations support the hypothesis that $\mathrm{Na}^{+} / \mathrm{Ca}^{2+}$ exchangers participate in the uterine $\mathrm{Ca}^{2+}$ secretion. The role of these transporters is clearly established at the mammalian intestinal and renal level [47]. Our study supported this mechanism for $\mathrm{Ca}^{2+}$ secretion in the chicken uterus, as both $\mathrm{Na}^{+} / \mathrm{Ca}^{2+}$ exchangers (SLC8A1 and 3) were overexpressed in the uterus compared to the magnum, whereas their expression did not change in the presence or absence of eggshell mineralisation (Figures 2 and 3). The mammalian exchangers allow the cell output of one $\mathrm{Ca}^{2+}$ ion against three $\mathrm{Na}^{+}$ions at the basolateral membrane level. This transport is facilitated by the $\mathrm{Na}^{+}$ gradient, which provides the energy necessary for the $\mathrm{Ca}^{2+}$ output against its gradient $[34,47]$. Similarly, the respective $\mathrm{Na}^{+}$gradient between the cell $(12 \mathrm{mM})$ and the uterine fluid (80 to $144 \mathrm{mM}$, Table 1) may provide the bird uterus with the energy needed for the $\mathrm{Ca}^{2+}$ output towards the uterine fluid at the apical membrane of the glandular cells. Conversely, the unfavourable gradient of $\mathrm{Na}^{+}$concentrations between blood $(140 \mathrm{mM})$ and glandular cells at the basal membrane level will prevent $\mathrm{Ca}^{2+}$ uptake in the cells by exchange with $\mathrm{Na}^{+}$. Both $\mathrm{Na}^{+} / \mathrm{Ca}^{2+}$ exchangers (SLC8A1 and 3) are therefore predicted to be present only in the apical membrane of the uterine glandular cells. The co-expression of the SLC8A1 and 3 genes and of ATP2BX is observed in numerous $\mathrm{Ca}^{2+}$ transporting epithelia [48-51] but their respective involvements in $\mathrm{Ca}^{2+}$ flux has been questioned. $\mathrm{Na}^{+} / \mathrm{Ca}^{2+}$ exchangers have a weak affinity for $\mathrm{Ca}^{2+}$, but strong $\mathrm{Ca}^{2+}$ conductance. On the other hand, the $\mathrm{Ca}^{2+}$ ATP2BX pumps have a strong affinity for $\mathrm{Ca}^{2+}$, but a weaker conductance [26]. These data suggest that $\mathrm{Ca}^{2+}$ transport is mainly assured by the $\mathrm{Na}^{+} / \mathrm{Ca}^{2+}$ exchangers. In the hen uterus, the inhibition of the $\mathrm{Na}^{+} / \mathrm{K}^{+}$ATPase led to a $60 \%$ decrease in $\mathrm{Ca}^{2+}$ transport in vitro or during uterine perfusion $[9,17]$. This observation underlines the importance of the $\mathrm{Na}^{+} / \mathrm{Ca}^{2+}$ exchangers in the avian uterus.

The information on uterine $\mathrm{Ca}^{2+}$ transport is summarized in the model described in Figure 4.

\section{$\mathrm{Na}^{+}$transfer}

During eggshell calcification, $\mathrm{Na}^{+}$is absorbed from the uterine fluid into the blood plasma. This absorption resulting from the predominance of apical to basolateral flux relative to basolateral to apical flux, is partly due to the presence of the $\mathrm{Na}^{+} / \mathrm{Ca}^{2+}$ exchangers (SLC8A1 and 3), but a complementary system has been demonstrated by using epithelial $\mathrm{Na}^{+}$channel blockers [31]. Amiloridesensitive $\mathrm{Na}^{+}$channels are essential in various epithelia [52]. Three subunits (SCNN1A, 1B, 1 G) of the $\mathrm{Na}^{+}$ channel are overexpressed in the uterus compared to the magnum and to the duodenum (Figure 2), suggesting the involvement of these transporters in $\mathrm{Na}^{+}$uptake by the uterine glandular cells at the apical membrane. The $\gamma$ subunit (SCNN1G) was overexpressed during shell calcification in contrast to the $\alpha$ and $\beta$ subunits (SCNN1A, 1B) suggesting its predominant involvement in the uterus.

In the basolateral membrane, the $\mathrm{Na}^{+}$glandular cell output towards plasma is active and occurs against a large electrochemical gradient (Table 1). This is provided by the $\mathrm{Na}^{+} / \mathrm{K}^{+}$ATPase, which is crucial in all animals for actively transporting $\mathrm{Na}^{+}$out and $\mathrm{K}^{+}$into the cell, and for maintaining the membrane potential and active transport of other solutes in intestine, kidney or placenta $[34,53]$. Its presence in the avian uterus and crucial role in ionic transfer during shell formation has been demonstrated $[8-10,17]$. In situ hybridization in the chicken uterus [18] showed that only the $\alpha 1$ subunit of $\mathrm{Na}^{+} / \mathrm{K}^{+}$ ATPase (ATP1A1), is present in the uterus whereas the $\alpha 2$ and $\alpha 3$ subunits (ATP1A2, A3) are absent. In this study, the $\alpha 1$ subunit (ATP1A1), but also the $\beta 1$ subunit of $\mathrm{Na}^{+} / \mathrm{K}^{+}$ATPase (ATP1B1), were overexpressed in the uterus compared to the magnum. We also confirmed the overexpression of $\alpha 1$ subunit of $\mathrm{Na}^{+} / \mathrm{K}^{+}$ATPase during the phase of calcification in contrast to the $\beta 1$ subunit of $\mathrm{Na}^{+} / \mathrm{K}^{+}$ATPase, in agreement with Lavelin et al. [18].

The possibility of an uptake of $\mathrm{Na}^{+}$from plasma into the uterine glandular cells at the basal membrane via $\mathrm{Na}^{+} / \mathrm{HCO}_{3}^{-}$co-transporters (SLC4A4, $5,7,10$ ) is discussed in the section addressing $\mathrm{HCO}_{3}^{-}$transfer.

\section{$\mathrm{K}^{+}$secretion}

In the gastrointestinal or kidney epithelia, $\mathrm{K}^{+}$channels provide the driving force for electrogenic transport processes across membranes and are involved in cell volume regulation or in secretory and reabsorptive processes. $\mathrm{K}^{+}$ channels are crucial for maintenance of body homeostasis and form the largest group of ion channels in mammals as more than one hundred thirty genes have been identified in human [54,55]. The chicken database revealed more than 80 such genes in birds. We explored only a limited number of $\mathrm{K}^{+}$channel candidates in chicken uterus by selecting $4 \mathrm{~K}^{+}$channels overexpressed in uterus compared to their expression in magnum, as revealed in our hen transcriptomic study [21]. The increased $\mathrm{K}^{+}$concentrations in uterine fluid between early ( 8 hours) and late stages of calcification (Table 1 ), demonstrates that uterine $\mathrm{K}^{+}$net flow corresponds to a secretion into uterine fluid. A portion of $\mathrm{K}^{+}$secretion might be associated with the passive component of water secretion which occurs during the egg plumping at the early stage of shell calcification (up to 10 hours) but no experimental data has explored this contribution through a putative paracellular pathway. $\mathrm{K}^{+}$uptake at the basolateral membrane, from the blood plasma 


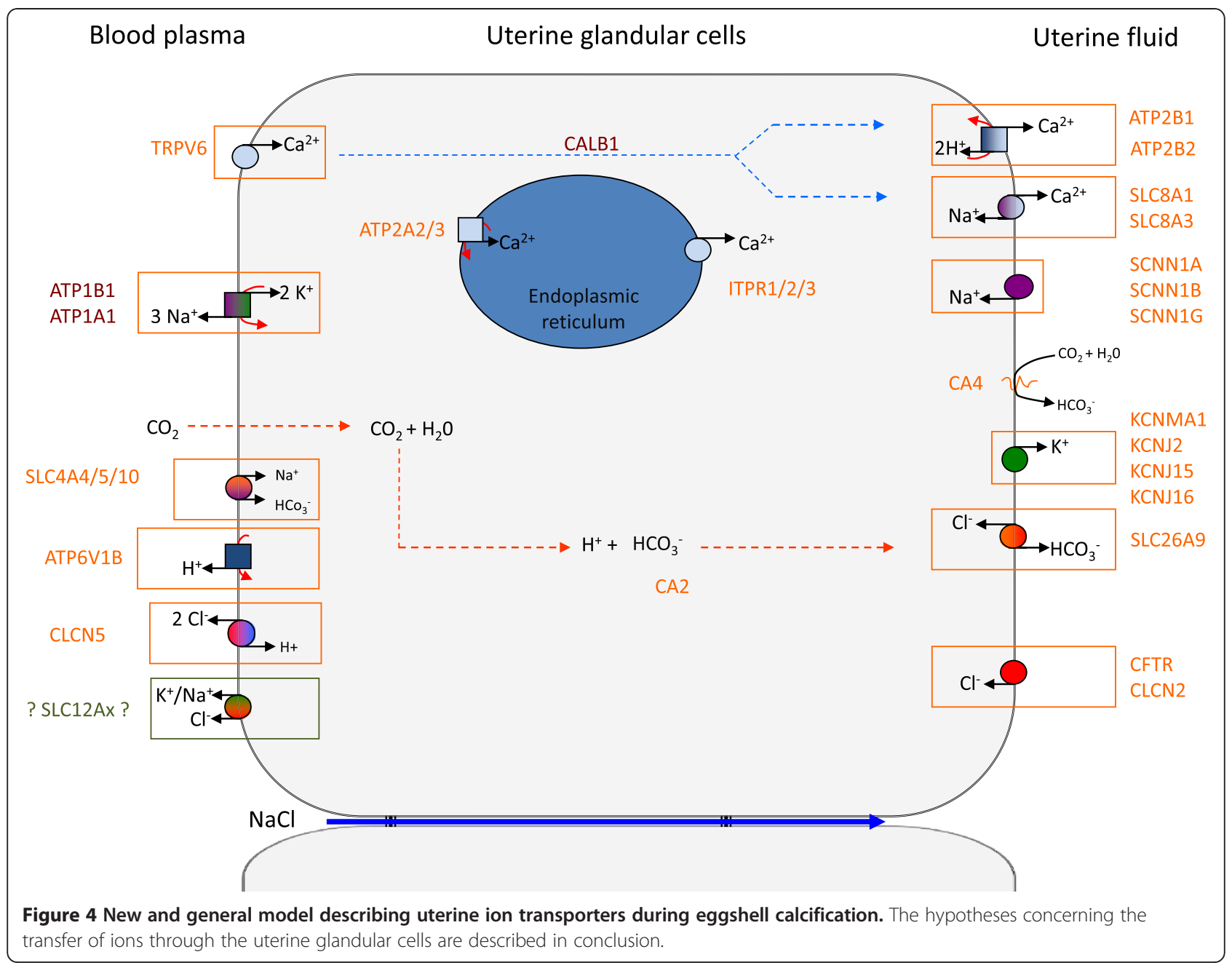

towards the uterine glandular cells, should result from activities of the $\mathrm{Na}^{+} / \mathrm{K}^{+}$ATPases (ATP1A1, B1). By analogy with other intestinal, kidney, pancreatic, placenta, mammary glands or blood cells, we expect that $\mathrm{K}^{+}$channels present in the glandular cell will recycle $\mathrm{K}^{+}$to allow functioning of the active $\mathrm{Na}^{+} / \mathrm{K}^{+}$ATPases. We tested 4 genes: three coding $\mathrm{K}^{+}$channels $(\mathrm{KCNJ} 2,15,16)$ and one $\mathrm{K}^{+}$large conductance $\mathrm{Ca}^{2+}$ activated channel (KCNMA1), which could be involved in $\mathrm{K}^{+}$cell output (Tables 1 and 3). The KCNJ2, 15, 16 channels belong to the KCNJ family (potassium inwardly-rectifying channel, subfamily J) which are stimulated by external $\mathrm{K}^{+}$concentration. Their expressions are observed in numerous epithelia where $\mathrm{K}^{+}$secretion occurs [54-56]. The KCNMs $\left(\mathrm{K}^{+}\right.$large conductance $\mathrm{Ca}^{2+}$ activated channels, subfamily $\mathrm{M}$ ) participate in $\mathrm{K}^{+}$output in a large range of tissues and epithelia and are regulated by $\mathrm{Ca}^{2+}$ cellular levels [54-56]. Our results showed that the expression of KCNJ2, 15, 16 and KCNMA1 $\mathrm{K}^{+}$channels were higher in the uterus compared with the magnum. Moreover, the expression of KCNJ2, 15 and KCNMA1 (KCNM subunit $\alpha$ ) was stimulated during calcification (Figure 3). These results showed that $\mathrm{KCNJ} 2,15,16$, and $\mathrm{KCNM} \mathrm{K}{ }^{+}$ channels are involved in the maintenance of potential membrane and $\mathrm{K}^{+}$recycling during eggshell calcification and have therefore been introduced in the model (Figure 4). We propose to localize them in the apical membrane but we have no evidence that they are absent from the basolateral membranes.

\section{$\mathrm{HCO}_{3}^{-}$production and transfer}

Eggshell mineralisation results from the co-precipitation of $\mathrm{Ca}^{2+}$ and $\mathrm{HCO}_{3}^{-}$. The bicarbonate precursor of the eggshell calcite is mainly derived from the blood carbon dioxide $\left(\mathrm{CO}_{2}\right)$ which penetrates the uterine glandular cells by simple diffusion through the plasma membrane $[2,19]$. Carbonic anhydrases (CAs) [6] catalyse the hydration of intracellular $\mathrm{CO}_{2}$ to $\mathrm{HCO}_{3}^{-}$, which is secreted into the uterine fluid. In the mammalian gastrointestinal tract, including pancreas, the cellular and membrane bound CAs are key enzymes allowing secretion or reabsorption of large amount of acid across the mucosa or 
protect epithelial cells from acid injury by secreting bicarbonate $[24,25,57]$. In all mammalian species, the duodenum buffers gastric acid secretion by producing intracellular $\mathrm{HCO}_{3}^{-}$from $\mathrm{CO}_{2}$ at a higher rate than the stomach or distal small intestine. The $\mathrm{CO}_{2}$ originates from intestinal lumen at the duodenal level but is provided from blood plasma via the respiratory system to the uterine tissue [1]. This study showed a larger expression of the cytosolic CA2 and 7 and of the membrane bound CA4 in the chicken uterus than in magnum (Figure 2). No difference in expression was observed between the uterus and the duodenum for CA2 and 4. Cytoplasmic CA2 is the predominant $\mathrm{CA}$ in the duodenum, playing a major function in the hydration of $\mathrm{CO}_{2}$ to produce $\mathrm{HCO}_{3}^{-}$[25]. Similarly, we propose that CA2 plays a major role in the uterus to provide the carbonate precursor for the eggshell. CA7 is significantly underexpressed in the uterus compared to the duodenum, suggesting a secondary rule in $\mathrm{HCO}_{3}^{-}$uterine production. A major role for $\mathrm{CA} 2$ is supported by the overexpression of this CA gene in the presence of eggshell mineralisation, in contrast to CA4 and 7 (Figure 3).

The $\mathrm{HCO}_{3}^{-}$produced by $\mathrm{CA} 2$ in uterine glandular cells must be then secreted into the uterine fluid to build the eggshell. In mammalian pancreas [57] and in duodenum [25] which secrete large amounts of $\mathrm{HCO}_{3}^{-}$towards the lumen, anion $\mathrm{HCO}_{3}^{-} / \mathrm{Cl}^{-}$exchangers (SLC4AX) have been located in apical membrane and $\mathrm{Na}^{+} / \mathrm{HCO}_{3}^{-}$cotransporters (SLC26AX) at the basolateral membrane $[58,59]$. In the bird uterus, there is a strong association between $\mathrm{HCO}_{3}^{-}$secretion and $\mathrm{Cl}^{-}$transport $[9,31]$ which supports the involvement of $\mathrm{HCO}_{3}^{-} / \mathrm{Cl}^{-}$exchangers. The $\mathrm{HCO}_{3}^{-}$flow through the uterine apical membrane is an electrogenic process which is facilitated by output of intracellular $\mathrm{Cl}^{-}$, via an exchanger of the SLC26 electrogenic family $[31,57]$. Our study confirmed the expression of a $\mathrm{HCO}_{3}^{-} / \mathrm{Cl}^{-}$exchanger (SLC26A9) in the uterus as shown in other epithelial cells [59]. SLC26A9 is suspected to have a role in intestinal $\mathrm{HCO}_{3}^{-}$secretion, in particular to neutralise gastric acidity [60,61]. Our results showed an overexpression of SLC26A9 exchanger in the uterus compared to the magnum or when the calcification takes place, whereas no variation of expression was observed between the duodenum and the uterus (Figure 2). These observations suggest a common mechanism between both tissues and support the hypothesis of the involvement of this transporter in the supply of $\mathrm{HCO}_{3}^{-}$for eggshell calcification. $\mathrm{Na}^{+} / \mathrm{HCO}_{3}^{-}$cotransporter genes (SLC4A4, 5, 7, 10; [58,62]) are also expressed in the uterus and likely contribute to $\mathrm{HCO}_{3}^{-}$ transport. SLC4A4, 5, 7 and 10 showed higher expression in the uterus than in the magnum. An overexpression relative to the duodenum is observed only for SLC4A5, the three others being similarly expressed
(Figure 2). SLC4A7 is underexpressed in the uterus during calcification compared to its absence (Figure 3) suggesting that involvement of this transporter is limited during the eggshell calcification process. In mammals, $\mathrm{Na}^{+} / \mathrm{HCO}_{3}^{-}$co-transporters mediate the electroneutral movement of $\mathrm{Na}^{+}$and $\mathrm{HCO}_{3}^{-}$across the plasma membrane [58]. The ionic concentrations in the plasma and uterine glandular cells (Table 1) show a favourable concentration gradient for uptake of these ions, supporting the localisation of these transporters in the basolateral membrane of uterine glandular cells to allow $\mathrm{HCO}_{3}^{-}$ entry. However, previous studies [2,19] showed that the majority of $\mathrm{HCO}_{3}^{-}$used for the eggshell came from blood $\mathrm{CO}_{2}$ and only for a minor part from plasma $\mathrm{HCO}_{3}^{-}$. $\mathrm{Na}^{+} / \mathrm{HCO}_{3}^{-}$co-transporters (SLC4A4, 5, 10) are likely to have a minor role in $\mathrm{HCO}_{3}^{-}$supply to the uterine glandular cells. The cystic fibrosis transmembrane conductance regulator (CFTR) contributes to fluid secretion from epithelial cells of the lung, pancreas and intestine, as shown in pathological situations associated with impaired fluid production, $\mathrm{Cl}^{-}$and $\mathrm{HCO}_{3}^{-}$secretion due to defective CFTR $[63,64]$ or in pharmacological studies of reproductive epithelium [65]. Its contribution to $\mathrm{HCO}_{3}^{-}$secretion is unlikely because of the unfavourable gradient or it is possibly indirect through regulation of $\mathrm{HCO}_{3}^{-}$transporters [65]. Its role as a $\mathrm{Cl}^{-}$channel is discussed in the following section on $\mathrm{Cl}^{-}$. Studies using specific inhibitors and measuring $\mathrm{Cl}^{-}$and $\mathrm{HCO}_{3}^{-}$flows are needed to quantify the contribution of $\mathrm{HCO}_{3}^{-} / \mathrm{Cl}^{-}$ exchangers in $\mathrm{HCO}_{3}^{-}$uterine secretion.

\section{$\mathrm{H}^{+}$transfer}

$\mathrm{HCO}_{3}^{-}$production in the glandular epithelial cells, its secretion into uterine fluid and the co-precipitation of $\mathrm{CO}_{3}^{2-}$ with $\mathrm{Ca}^{2+}$ leads to a progressive acidification of the uterine fluid and of glandular cells $[1,5]$. In fact, two $\mathrm{H}^{+}$ are produced for each $\mathrm{CaCO}_{3}$ formed. This metabolic acidosis is partially compensated by hyperventilation by the hen and by an increased renal $\mathrm{H}^{+}$excretion [22].

The plasma membrane $\mathrm{Ca}^{2+}$-transporting ATPases (ATP2B1, 2) of the apical membrane actively extrude $\mathrm{Ca}^{2+}$, as previously mentioned. However several lines of evidence have established that these pumps contribute to $\mathrm{H}^{+}$re-absorption coupled to $\mathrm{Ca}^{2+}$ secretion $[66,67]$. The present study highlights their crucial role in $\mathrm{Ca}^{2+}$ secretion by uterine glandular cells during eggshell formation and therefore in $\mathrm{H}^{+}$re-absorption from the uterine fluid through the apical membrane. Alternatively, the $\mathrm{Na}^{+} / \mathrm{H}^{+}$exchangers have been shown to contribute to $\mathrm{H}^{+}$output in the pancreatic duct which also secretes large amount of $\mathrm{HCO}_{3}^{-}$. In a recent transcriptomic study of the uterus (unpublished data, Brionne A, Nys Y and Gautron J), we detected expression of various $\mathrm{Na}^{+} / \mathrm{H}^{+}$ 
exchangers (SLC9A 1, 2, 6, 7, 8, 9), supporting this possibility.

In this study, RT-PCR shows that the $\mathrm{V} \mathrm{H}^{+}$ATPase pump (VAT) is expressed in the bird uterus during calcification. In mammals, this VAT complex is made up of at least 14 subunits and allows transfer of $\mathrm{H}^{+}$by hydrolysis of ATP [68,69]. This VAT is present in many membranes of organelles and also frequently in the plasma membranes of renal cells or osteoclasts [70]. VAT is therefore a good candidate for transferring protons to plasma in the hen uterine glandular cell, especially as this VAT was revealed in other species producing $\mathrm{CaCO}_{3}$ biominerals and shown to export $\mathrm{H}^{+}$ during mineralisation [71,72]. This proton ATPase extrudes $\mathrm{H}^{+}$across the basolateral membrane of pancreatic duct epithelium [57] which is secreting high amounts of $\mathrm{HCO}_{3}^{-}$using mechanisms quite similar to uterine glandular cells. Our study reveals overexpression of the VAT subunit B in the uterus, which transfers large amounts of $\mathrm{H}^{+}$compared with the magnum, where limited amounts of $\mathrm{H}^{+}$are transferred. The VAT is likely to participate in $\mathrm{H}^{+}$export from cytoplasm of the uterine cells to the blood plasma across the plasma membrane. The role of CLCN5 in $\mathrm{H}^{+}$transfer is discussed in the ensuing $\mathrm{Cl}^{-}$section.

\section{$\mathrm{Cl}^{-}$transfer}

The $\mathrm{Cl}^{-}$concentrations decrease from 71 to $45 \mathrm{mM}$ in the uterine fluid (Table 1) when comparing the initial and late stage of eggshell calcification in parallel with changes of larger magnitude in $\mathrm{Na}^{+}$concentrations. The high concentration of these ions observed at the early stage of calcification might result from the large secretions of water, $\mathrm{Na}^{+}$and $\mathrm{Cl}^{-}$which occurs during the plumping period (hydration of the egg white proteins), 6 to $10 \mathrm{~h}$ after ovulation possibly through a paracellular pathway [1]. These water and saline secretions are completed at the initiation of the rapid phase of shell formation, when $\mathrm{Na}^{+}$and $\mathrm{Cl}^{-}$net fluxes are inversed. The net flux of $\mathrm{Cl}^{-}$is inhibited by acetazolamide, demonstrating the relationship between $\mathrm{Cl}^{-}$transport and $\mathrm{HCO}_{3}^{-}$secretion derived from CAs activity $[8,9,31]$, and the involvement of $\mathrm{HCO}_{3}^{-} / \mathrm{Cl}^{-}$exchangers of the SLC4 or SLC26 family $[57,62,73]$. Amongst the SLC4Ax $\mathrm{HCO}_{3}^{-} / \mathrm{Cl}^{-}$ exchangers, we observed no expression of SLC4A8 and there is no evidence of any expression of SLC4A1, 2 or 3 in avian uterine transcriptomic study [21]. The role of SLC26A9 exchanger was previously discussed in the $\mathrm{HCO}_{3}^{-}$section. This exchanger is predicted to be located in the apical membrane of the uterine glandular cells and to contribute to $\mathrm{Cl}^{-}$cell uptake during eggshell calcification as suggested in hens subjected to acetazolamide inhibitors [31] or in other species [57,59].
The CLCN2 channel, a family member of the CLCN $\left(\mathrm{Cl}^{-}\right.$channel), is relatively ubiquitous in epithelial cells and other cellular types $[74,75]$. It is considered to participate in various functions such as cellular volume regulation [76,77], cardiac activity regulation $[78,79]$ and $\mathrm{Cl}^{-}$trans-epithelial transfer $[80,81]$. Our study revealed that the CLCN2 channel is overexpressed in the uterus compared to the magnum or the duodenum (Figure 2). The uterine fluid $(>45 \mathrm{mM})$ and intracellular $(4 \mathrm{mM}) \mathrm{Cl}^{-}$ concentrations are favourable to a $\mathrm{Cl}^{-}$passive entry in uterine glandular cells. In parallel, another $\mathrm{Cl}^{-}$channel, the cystic fibrosis transmembrane conductance regulator (CFTR) could also contribute to $\mathrm{Cl}^{-}$entry in the cell as observed in numerous tissues [74]. In the chicken uterus, the CFTR channel is expressed at a higher level than in the magnum and the duodenum (Figure 2). It is also overexpressed in the uterus during eggshell calcification (Figure 3). The CLCN2 and CFTR channel are therefore probably expressed in the apical membrane and might contribute to $\mathrm{Cl}^{-}$entry in the cell.

On the other hand, $\mathrm{Cl}^{-}$output could be carried out by CLCN5, another member of CLCN family. Renal proximal tubule cells highly express the $\mathrm{V} \mathrm{H}^{+}$ATPase for acidification of endosomes and electroneutrality is ensured by transfer of $\mathrm{Cl}^{-}$by CLCN5 [74]. The CLCN5 $\mathrm{H}^{+} / \mathrm{Cl}^{-}$exchanger [75] has been localised mainly in organelle membranes but also in the plasma membrane. Our study revealed an overexpression of CLCN5 $\mathrm{H}^{+} / \mathrm{Cl}^{-}$ in the uterus compared to the magnum, so this channel might contribute to $\mathrm{Cl}^{-}$output through the basal membrane. An alternative would be that $\mathrm{Cl}^{-}$output relies on cation-coupled cotransport as observed in fish or mammals. The SLC12 family consists of $\mathrm{Na}^{+}-\mathrm{K}^{+}-2 \mathrm{Cl}^{-}$cotransporters and of $\mathrm{K}^{+}-\mathrm{Cl}^{-}$electroneutral cotransporters, and are expressed either in kidney where they contribute to salt reabsorption, or more ubiquitously being involved in cell volume regulation [82-84]. In the chicken uterus, one $\mathrm{Na}^{+}-\mathrm{K}^{+}-2 \mathrm{Cl}^{-}$cotransporter (SLC12A2) and $4 \mathrm{~K}^{+}-\mathrm{Cl}^{-}$ cotransporters (SLC12A4, 7, 8, 9) are putative candidate, as expression of these genes is revealed in the chicken uterus transcriptome (unpublished data, Brionne A, Nys $\mathrm{Y}$ and Gautron J). In addition, furosemide, a blocker of $\mathrm{Na}^{+}-\mathrm{K}^{+}-2 \mathrm{Cl}^{-}$cotransporters, has been shown to decrease egg shell thickness [85].

\section{Conclusions}

Initial studies on ion transfer in the uterus using physiological and pharmacological approaches provided a preliminary model of ion transfer contributing to the uterine $\mathrm{Ca}^{2+}$ and $\mathrm{HCO}_{3}^{-}$necessary for shell mineralisation (Figure 1) $[1,5,8-10,17]$. The current approaches using knowledge gleaned from the chicken genome sequence and uterine transcriptomic expression data [21] identified numerous genes encoding putative transporters 
Table 3 Primers used for RT-PCR and qRT-PCR of ion transporter genes

\begin{tabular}{|c|c|c|c|}
\hline Gene symbol & RefSeq accession & Forward primer & Reverse primer \\
\hline TPRV6 & XM_416530 & AACACCTGTGAAGGAGCTGGTGAG & TCTGCTGCTTGTTITGTTGCC \\
\hline CALB1 & NM_205513 & CAGGGTGTCAAAATGTGTGC & GCCAGTTCTGCTCGGTAAAG \\
\hline ATP2A1 & NM_205519 & AAGGGGGGGTCTITAAGGATGG & CAAACTGCTCCACCACCAACTC \\
\hline ATP2A2 & XM_415130 & GCAGCTTGCATATCTTITGTGCTG & CATTTCTTTCCTGCCACACTCC \\
\hline ATP2A3 & NM_204891 & CAACCCCAAGGAGCCTCTTATC & GGTCCCTCAGCGTCATACAAGAAC \\
\hline ITPR1 & XM_414438 & AATGGCAAAAGGCGAGGAAAGC & GGAGCAGCAGCAAGCGGG \\
\hline ITPR2 & XM_001235612 & TGAGCATTGTGAGTGGCTTC & GTTGACCTGGCTGTCCAAAT \\
\hline ITPR3 & XM_418035 & AGTACAACGTGGCCCTCATC & GTCGTGTCTGCTCTCCATGA \\
\hline RYR1 & X95266 & GTTCCTCTGCATCATCGGCTAC & AATTGCTGGGGAAGGACTGTG \\
\hline ATP2B1 & XM_416133 & CTGCACTGAAGAAAGCAGATGTTG & GCTGTCATATACGTTTCGTCCCC \\
\hline ATP2B2 & XM_001231767 & TTACTGTACTTGTGGTTGCTGTCCC & GGTTGTTAGCGTCCCTGTTTTG \\
\hline ATP2B4 & XM_418055 & GCTGGTGAAGTTGTCATCCGTC & TGCTCTGAAGAAAGCTGATGTTGG \\
\hline SLC8A1 & NM_001079473 & GGATTGTGGAGGTTTGGGAAGG & CTGTTTGCCAGCTCGGTATTTC \\
\hline SLC8A3 & XM_001231413 & GGAGAGACCACAACAACAACCATTC & AGCTACGAATCCATGCCCACAC \\
\hline SCNN1A & NM_205145 & GCTTGCCAGAAAACAGTCCCTC & AGTCAGACTCATCCAGGTCTTTGG \\
\hline SCNN1B & XM_425247 & ATGGAAGTAGACCGCAGT & GTTGTATGGCAGCACAGT \\
\hline SCNN1G & XM_414880 & CAAAAGGCACTTCACCCGTTTC & GGACAATGATCTTGGCTCCTGTC \\
\hline ATP1A1 & NM_205521 & GCACAAAGAAGAAAAAGGCGAAGG & GGGTGGAGGTGTAAGGGTATTTG \\
\hline ATP1B1 & NM_205520 & TCTGGAACTCGGAGAAGAAGGAG & GACGGTGAGCAACATCACTTGG \\
\hline SLC4A4 & XM_420603 & GGAAAGCACCATTCTTCGCC & CCTCCAAAAGTGATAGCATTGGTC \\
\hline SLC4A5 & XM_423797 & TGAACGTCTCCGCTACATCCTG & ACTITATCCACCTGGCTGACTCC \\
\hline SLC4A7 & XM_418757 & AAATTGCCAAGTTCGTGGTGG & GCGAAGCAAATGAGAAGTTACGG \\
\hline SLC4A9 & XM_001232427 & TCCTGACTGGAGTCTCTGTCTTCC & AGGTGATCTGGCTGGTGTITG \\
\hline SLC4A10 & XR_026836 & CGCTGATGACAGATGAGGTGTTC & GGTGGTTCTATTCGGATTGTTGG \\
\hline KCNJ2 & NM_205370 & CCATTGCTGTITCATGGTG & TCCTGGACTTGAGGAGCTGT \\
\hline KCNJ15 & XM_425554 & TGAGGGAAGGGAGACTCTGA & GCTTCCATCCTCACTGCTTC \\
\hline KCNJ16 & XM_425383 & САTTCCTGTTCTCCCTGGAA & CATTITAGCCAAGGCTGCTC \\
\hline KCNMA1 & NM_204224 & GGGATGATGCGATCTGTCTT & GACAAACCCACAAAGGCACT \\
\hline CA2 & NM_205317 & ATCGTCAACAACGGGCACTCCTTC & TGCACCAACCTGTAGACTCCATCC \\
\hline CA4 & XM_415893 & GCTAACACATTITTCCCCCTTCC & CTITATAGCACATCGCATCAGCC \\
\hline CA7 & XM_414152 & GCACAAGTCTTATCCCATTGCC & GCCGTTGTTGGAGATGTTGAGAG \\
\hline SLC4A8 & XM_001235579 & AGAAGAAGAAGTTGGACGATGCC & GGTCAGTTCTGTCCTTGCTGTTCTG \\
\hline SLC26A9 & XM_425821 & GCCTCTTCGATGAGGAGTTTGAG & CTGACCCCACCAAGAACATCAG \\
\hline ATP6V1B2 & XM_424534 & ATTCTCTGCTGCTGGTTTGCCC & CATGGACCCATITTCCTCAAAGTC \\
\hline CFTR & NM_001105666 & AAGAGGGCAGGGAAGATCAACGAG & CGGGTTAGCTTCAGTTCAGTTTCAC \\
\hline CLCN2 & XM_423073 & CCTGGACACCAATGTGATGCTG & CACGAAGGTCTTCAGGGTGAGATAC \\
\hline CLCN5 & XM_420265 & CGATTGGAGGAGTGCTCTITAGTC & CAAAAGGATTGATGGAACGCAG \\
\hline
\end{tabular}

supplying the mineral precursors of eggshell mineralisation. We have used this information to build a model describing the ion supply mechanisms in the uterus, following a logical sequence for ion transfers for secretion of large amounts of $\mathrm{Ca}^{2+}$ and $\mathrm{HCO}_{3}^{-}$to form the eggshell (Figure 4). This work identified 31 genes and related proteins involved in this process. It is consistent with preliminary hypotheses. Our analysis also revealed that analogies exist in the mechanisms of $\mathrm{HCO}_{3}^{-}$secretion by pancreatic duct cells and by duodenum, and to a lower extent with intestinal epithelial cells for $\mathrm{Ca}^{2+}$ movement, even if the $\mathrm{Ca}^{2+}$ flux is reversed between both uterus and duodenum.

The main steps of ion transfer in the hen's uterus can be summarised (as presented in Figure 4):

(1) $\mathrm{Ca}^{2+}$ secretion through epithelial glandular cells involves TRPV6 $\mathrm{Ca}^{2+}$ channel in the basolateral membrane (cell uptake entry), $28 \mathrm{kDa}$ calbindin (CALB1, intracellular transfer), endoplasmic $\mathrm{Ca}^{2+}$ pumps type 2, 3 (ATP2A2, 3, uptake by endoplasmic 
reticulum), and inositol trisphosphate receptors type 1, 2, 3 (ITPR1, 2, 3, output from the reticulum). $\mathrm{Ca}^{2+}$ is then extruded from the glandular cells by the membrane's $\mathrm{Ca}^{2+}$ pumps (ATP2B1, 2) and $\mathrm{Ca}^{2+} / \mathrm{Na}^{+}$exchangers (SLC8A1, 3). The endoplasmic $\mathrm{Ca}^{2+}$ pumps, inositol trisphosphate receptors, and $28 \mathrm{kDa}$ calbindin contribute to maintain a low intracellular free $\mathrm{Ca}^{2+}$ concentration essential for cell survival.

(2) $\mathrm{Na}^{+}$transport involves three $\mathrm{Na}^{+}$channels (subunits SCNN1A, 1B, $1 \mathrm{G}$; uptake in the cell), $\mathrm{Na}^{+} / \mathrm{Ca}^{2+}$ exchangers SLC8A1 and 3 (uptake in the cell) and the $\mathrm{Na}^{+} / \mathrm{K}^{+}$ATPase (ATP1A1, ATP1B1, output from the cell).

(3) $\mathrm{K}^{+}$uptake entry into the cell results from the $\mathrm{Na}^{+} / \mathrm{K}^{+}$ATPase; the $\mathrm{K}^{+}$channels (KCNJ2, 15, 16 and KCNMA1) contribute to its output release at the apical membrane.

(4) $\mathrm{HCO}_{3}^{-}$is mainly produced from $\mathrm{CO}_{2}$ by $\mathrm{CA} 2$ and to a lesser extent by $\mathrm{CA} 4$, and is also provided at a low level from plasma by the $\mathrm{Na}^{+} / \mathrm{HCO}_{3}^{+}$ co-transporters (SLC4A4, 5, 10). $\mathrm{HCO}_{3}^{-}$is exported from the cell through the $\mathrm{HCO}_{3}^{-} / \mathrm{Cl}^{-}$exchanger SLC26A9.

(5) $\mathrm{HCO}_{3}^{-}$synthesis in the cell and co-precipitation of $\mathrm{HCO}_{3}^{-}$with $\mathrm{Ca}^{2+}$ in the uterine fluid produces two $\mathrm{H}^{+}$which are transferred to plasma via the membrane $\mathrm{Ca}^{2+}$ pumps ATP2B1, 2 in the apical membrane and the VAT pump at the basolateral level.

(6) $\mathrm{Cl}^{-}$ions in the uterine fluid enter the cell by the $\mathrm{HCO}_{3}^{-} / \mathrm{Cl}^{-}$exchanger SLC26A9 and by $\mathrm{Cl}^{-}$channels (CLCN2, CFTR uptake in the cells), and might be extruded by $\mathrm{Cl}^{-} / \mathrm{H}^{+}$exchanger (CLCN5), but also by $\mathrm{Na}^{+}-\mathrm{K}^{+}-2 \mathrm{Cl}^{-}$and $\mathrm{K}^{+}-\mathrm{Cl}^{-}$cotransporters (SLC12Ax).

This model proposes a large but not exhaustive list of ionic transfer proteins involved in the supply of $\mathrm{Ca}^{2+}$ and $\mathrm{HCO}_{3}^{-}$or in maintaining cellular homeostasis (volume, electroneutrality). The model qualitatively describes putative mechanisms and cellular localisation of the candidates. These hypotheses relying on expression of the genes and on analogies with other tissues that transfer large amount of ions, need to be confirmed using immunochemistry for their cell localisation or by specific inhibition, to establish their relative contribution and understand their interaction and regulation. This avian model where huge amounts of $\mathrm{Ca}^{2+}$ and $\mathrm{HCO}_{3}^{-}$are exported daily following a precise spatial and temporal sequence should contribute to understanding the mechanism and regulation of ionic precursors of $\mathrm{CaCO}_{3}$ and provide insight for other species secreting a
$\mathrm{CaCO}_{3}$ biomineral such as coral, molluscs, foraminifera or sea urchins.

\section{Methods}

\section{Animals handling and housing}

The experiment was conducted at the Unité Expérimentale Pôle d'Expérimentation Avicole de Tours (UEPEAT - INRA, Tours, France) according to the legislation on research involving animal subjects set by the European Community Council Directive of November 24, 1986 (86/609/EEC) and under the supervision of an authorized scientist (Authorization \# 7323, J Gautron). Forty week old laying hens (ISA brown strain) were caged individually and subjected to a light/dark cycle of 14 hour light and 10 hour darkness (14 L:10D). The hens were fed a layer of mash as recommended by the Institut National de la Recherche Agronomique (INRA). Each cage was equipped with a device for automatic recording of oviposition time.

\section{Collection of laying hens oviduct tissues}

Tissue samples (magnum, uterus, duodenum, kidney and gastrocnemius) were harvested in 8 hens while the egg was in the uterus during the active phase of calcification (16-18 hour post-ovulation). Additionally, uterine tissues were collected from 8 birds injected with $50 \mu \mathrm{g}$ of F2- $\alpha$ prostaglandin during 4 consecutive days to expel the egg before mineralisation had begun (6 to 8 hours post ovulation). All tissue samples were quickly frozen in liquid nitrogen and stored at $-80^{\circ} \mathrm{C}$ until RNA extraction.

\section{Determination of Gallus gallus cDNA sequences involved in mineral supply and design of primers}

The list of ion transporters was established using recent transcriptomic data and Gallus gallus databases when available. The transporters not yet identified in chicken were identified using human orthologs in Swiss-Prot/ TrEMBL and RefSeq databases. The corresponding human sequences were aligned to Gallus gallus Refseq database using BlastN algorithm an e-value cut-off of $10^{-20}$. Primers (Table 3), were designed from the Gallus gallus using Mac vector software (MacVector, Cambridge, U.K.). The quality of the primers was tested by virtual PCR for dimerization and specificity using Amplify 3X software [86].

\section{RNA isolation, reverse transcription and classical}

Total RNA was extracted from frozen tissue samples using a commercial kit (RNeasy Mini kit, Qiagen; Courtaboeuf, France) and simultaneously treated with DNase (RNase-free DNase set, Qiagen; Courtaboeuf, France) according to the manufacturer's procedure. RNA concentrations were measured at $260 \mathrm{~nm}$ using 
a NanodropND 1000 (Thermo Fischer, Wilmington, Delaware, USA). The integrity of RNA was evaluated on a $2 \%$ agarose gel and with an Agilent 2100 Bioanalyser (Agilent Technologies, Massy, France). Only RNA samples with a $28 \mathrm{~S} / 18 \mathrm{~S}$ ratio $>1.3$ were considered for RT-PCR and qRT-PCR experiments. Total RNA samples $(5 \mu \mathrm{g})$ were subjected to reversetranscription using RNase H-MMLV reverse transcriptase (Superscript II, Invitrogen, Cergy Pontoise, France) and random hexamers (Amersham, Orsay, France). PCR was performed using primers (Table 3) for 30 cycles at $60^{\circ} \mathrm{C}$. The specificity of the PCR reaction was assessed by sequencing of PCR products (Cogenics, Meylan, France), and alignment of the sequences using BLASTN algorithm against the Gallus gallus RefSeq nucleic data bank.

\section{Quantitative RT-PCR (qRT-PCR)}

Alternatively, cDNA sequences were amplified in real time using the qPCR Master mix plus for SYBR ${ }^{\circledR}$ Green I assay (Eurogentec, Seraing, Belgium) with the ABI PRISM 7000 Sequence Detection System (Applied Biosystems, France). To account for variations in mRNA extraction and reverse transcription reaction between samples, mRNA levels were normalized either to ribosomal 18S rRNA levels for each sample in the first series of comparison (magnum, uterus, and duodenum) or to TBP (TATA box binding protein) for each samples in the second series of comparison (comparison of expression in the uterus with and without mineralisation). The expression levels of $18 \mathrm{~S}$ rRNA were measured using TaqMan Universal PCR Master Mix and developed TaqMan assay for human 18S rRNA (Applied Biosystems, Courtaboeuf, France) as previously validated [87]. The PCR conditions consisted of an uracil-N-glycosylase preincubation step at $50^{\circ} \mathrm{C}$ for $2 \mathrm{~min}$, followed by a denaturation step at $95^{\circ} \mathrm{C}$ for $10 \mathrm{~min}$, and 40 cycles of amplification (denaturation for $15 \mathrm{sec}$ at $95^{\circ} \mathrm{C}$, annealing and elongation for $1 \mathrm{~min}$ at $60^{\circ} \mathrm{C}$ ). A melting curve was carried out from 60 to $95^{\circ} \mathrm{C}$ for each sample amplified with SYBR ${ }^{\circledR}$ Green. Each run included triplicates of no template controls, standards and samples. Standards correspond respectively to a pool of the magnum, uterus, and duodenum RT products for the first series of experiments and of the uterus with and without mineralisation for the second series of comparison. The threshold cycle $(\mathrm{Ct})$, defined as the cycle at which fluorescence rises above a defined base line, was determined for each sample and cDNA control. A calibration curve was calculated using the $\mathrm{Ct}$ values of the cDNA control samples and relative amount of unknown samples were deduced from this curve. The ratio value was calculated for each sample as sample/18 $\mathrm{S}$ rRNA in the first comparison (magnum, uterus, and duodenum) or sample/TBP in the second comparison (uterus with and without calcification). The log of the ratio was used for statistical analysis using the $5^{\text {th }}$ version of StatView, software (SAS Institute Inc. Cary, NC). A one-way analysis of variance was performed to detect differences $(\mathrm{P}<0.05 ; 8$ replicates/treatment) in gene expression amongst different conditions.

\section{Additional file}

Additional file 1: Table 1. RT-PCR of the candidate genes potentially involved in ion transfer in four secreting tissues and in muscle.

\section{Competing interests}

The authors declare that they have no competing interests.

\section{Authors' contributions}

VJ, JG contributed to the strategy, the experimental design, and planning of the study. VJ carried out the experiments and analyses, interpreted data and wrote the first draft of the paper. JG is the supervisor of VJ (Ph.D. student). $A B$ contributed to the interpretation of data and to the writing of the paper. YN conceived the research program focused on identification of egg proteins. He was involved in the strategy, the experimental design, data interpretation and was fully involved in the writing of the paper. All authors have read and approved the final manuscript.

\section{Acknowledgements}

The authors gratefully acknowledge the European Community for its financial support through the RESCAPE project (RESCAPE Food CT 2006036018), and SABRE program (European Integrating project Cutting-Edge Genomics for Sustainable Animal Breeding Project 016250). VJ thanks the Region Centre and INRA for financial support. We also thank Magali Berges for her technical assistance and Jean Didier Terlot-Brysinne for care of experimental birds. We wish to thank Prof. Maxwell Hincke, Department of Cellular \& Molecular Medicine, University of Ottawa, 451 Smyth Road, Ottawa K1H 8 M5, Canada, for his critical reading of the manuscript and constructive remarks.

Received: 24 April 2012 Accepted: 16 August 2012 Published: 4 September 2012

\section{References}

1. Nys Y, Hincke MT, Arias JL, Garcia-Ruiz JM, Solomon SE: Avian eggshell mineralization. Poult Avian Biol Rev 1999, 10(3):143-166.

2. Hodges R, Lörcher K: Possible sources of the carbonate fraction of egg shell calcium carbonate. Nature 1967, 216:606-610.

3. Lippiello L, Wasserman RH: Fluorescent-antibody localization of vitamin-Ddependent calcium-binding protein in oviduct of laying hen. $J$ Histochem Cytochem 1975, 23(2):111-116.

4. Coty WA, McConkey CL: A high-affinity calcium-stimulated atpase activity in the hen oviduct shell gland. Arch Biochem Biophys 1982, 219(2):444-453.

5. Sauveur B, Mongin P: Comparative study of uterine fluid and egg albumen in shell gland of hen. Ann Biol Anim Biochim Biophys 1971, 11(2):213-224.

6. Common $\mathrm{RH}$ : The carbonic anhydrase activity of the hen oviduct. J Agri Soc Univ Coll Wales 1941, 31:412-414.

7. Pike JW, Alvarado $\mathrm{RH}$ : $\mathrm{Ca} 2+-\mathrm{Mg} 2+-$ activated atpase in shell gland of japanese-quail (Coturnix-coturnix-japonica). Comp Biochem Physiol B 1975, 51(1):119-125.

8. Eastin WC, Spaziani E: Control of calcium secretion in avian shell gland (Uterus). Biol Reprod 1978, 19(3):493-504.

9. Eastin WC, Spaziani E: On the mechanism of calcium secretion in the avian shell gland (Uterus). Biol Reprod 1978, 19(3):505-518.

10. Pearson TW, Goldner AM: Calcium-transport across avian uterus - Effects of electrolyte substitution. Am J Physiol 1973, 225(6):1508-1512.

11. Nys $Y$, Mayel-Afshar S, Bouillon R, Vanbaelen H, Lawson DEM: Increases in calbindin D-28 k messenger-Rna in the uterus of the domestic-fowl induced by sexual maturity and shell formation. Gen Comp Endocrinol 1989, 76(2):322-329. 
12. Striem S, Bar A: Modulation of quail intestinal and egg-shell gland calbindin (Mr 28000) gene-expression by vitamin-D3, 1,25-dihydroxyvitamin-D3 and egg-laying. Mol Cell Endocrinol 1991, 75(2):169-177.

13. Nys Y, Zawadzki J, Gautron J, Mills AD: Whitening of brown-shelled eggs: mineral composition of uterine fluid and rate of protoporphyrin deposition. Poult Sci 1991, 70(5):1236-1245.

14. Bar A, Striem S, Mayel-afshar S, Lawson DEM: Differential regulation of calbindin-D28K mRNA in the intestine and eggshell gland of the laying hen. J Mol Endocrinol 1990, 4(2):93-99.

15. Christakos S, Barletta F, Huening M, Dhawan P, Liu Y, Porta A, Peng X: Vitamin D target proteins: Function and regulation. J Cell Biochem 2003, 88(2):238-244

16. Parker SL, Lindsay LA, Herbert JF, Murphy CR, Thompson MB: Expression and localization of $\mathrm{Ca} 2+-$ ATPase in the uterus during the reproductive cycle of king quail (Coturnix chinensis) and zebra finch (Poephila guttata). Comp Biochem Physiol A 2008, 149(1):30-35.

17. Pearson TW, Goldner AM: Calcium-transport across avian uterus.ll. Effects of inhibitors and nitrogen. Am J Physiol 1974, 227(2):465-468.

18. Lavelin I, Meiri N, Genina O, Alexiev R, Pines M: $\mathrm{Na}+-\mathrm{K}+-$ ATPase gene expression in the avian eggshell gland: distinct regulation in different cell types. Am J Physiol Regul Integr Comp Physiol 2001, 281(4):R1169-R1176.

19. Lörcher K, Zscheile C, Bronsch K: Rate of $\mathrm{CO} 2$ and $\mathrm{C} 14$ exhalation in laying hens resting and during egg-shell mineralisation after a single injection of NaHC1403. Ann Biol Anim Biochim Biophys 1970, 10:133-139.20.

20. Consortium ICGS: Sequence and comparative analysis of the chicken genome provide unique perspectives on vertebrate evolution. Nature 2004, 432(7018):695-716

21. Jonchère $V$, Rehault-Godbert $S$, Hennequet-Antier $C$, Cabau $C$, Sibut $V$, Cogburn LA, Nys Y, Gautron J: Gene expression profiling to identify eggshell proteins involved in physical defense of the chicken egg. BMC Genomics 2010, 11:57.

22. Sauveur B: Electrolyte composition of different zones of egg albumen in 2 breeds of hen. Ann Biol Anim Biochim Biophys 1969, 9(4):563-573.

23. Bronner F, Pansu D: Nutritional aspects of calcium absorption. J Nutr 1999, 129(1):9-12.

24. Kaunitz JD, Akiba Y: Duodenal carbonic anhydrase: Mucosal protection, luminal chemosensing, and gastric acid disposal. Keio J Med 2006, 55(3):96-106.

25. Flemström G, Allen A: Gastroduodenal mucus bicarbonate barrier: protection against acid and pepsin. Am J Physiol Cell Physiol 2005, 288(1):1-19.

26. Bouillon R, Van Cromphaut S, Carmeliet G: Intestinal calcium absorption: Molecular vitamin D mediated mechanisms. J Cell Biochem 2003, 88(2):332-339.

27. Hurwitz S: Calcium homeostasis in birds. Vitam Horm 1989, 45:173-221.

28. Nys Y: Regulation of plasma 1,25 (OH)2D3, of osteocalcin and of intestinal and uterine calbindin in hens. In Avian Endocrinology. Edited by Sharp PJ. Bristol: Society for Endocrinology; 1993:345-357. 408p.

29. Nys Y: Régulation endocrinienne du metabolisme calcique chez la poule et calcification de la coquille. 6th edition. Paris: Thèse de Docteur de l'université en Physiologie animale; 1990:162p.

30. Bar A: Calcium transport in strongly calcifying laying birds: Mechanisms and regulation. Comp Biochem Physiol A 2009, 152(4):447-469.

31. Vetter AE, O'Grady SA: Sodium and anion transport across the avian uterine (shell gland) epithelium. J Exp Biol 2005, 208(3):479-486.

32. Wasserman RH, Smith CA, Smith CM, Brindak ME, Fullmer CS, Krook L, Penniston JT, Kumar R: Immunohistochemical localization of a calciumpump and calbindin-D28k in the oviduct of the laying hen. Histochemistry 1991, 96(5):413-418.

33. Wasserman RH, Taylor AN: Vitamin D3-induced calcium-binding protein in chick intestinal mucosa. Science 1966, 152(3723):791-793.

34. Hoenderop JGJ, Nilius B, Bindels RJM: Calcium absorption across epithelia. Physiol Rev 2005, 85(1):373-422.

35. Jande S, Tolnai S, Lawson D: Immunohistochemical localization of vitamin D-dependent calcium-binding protein in duodenum, kidney, uterus and cerebellum of chickens. Histochemistry 1981, 71(1):99-116.

36. Lambers TT, Mahieu F, Oancea E, Hoofd L, de Lange F, Mensenkamp AR, Voets T, Nilius B, Clapham DE, Hoenderop JG, et al: Calbindin-D-28 K dynamically controls TRPV5-mediated Ca2+ transport. EMBO J 2006, 25(13):2978-2988.
37. Christakos S, Dhawan P, Benn B, Porta A, Hediger M, Oh GT, Jeung EB, Zhong Y, Ajibade D, Dhawan K, et al: Vitamin D molecular mechanism of action. Ann N Y Acad Sci 2007, 1116:340-348.

38. Gorlach A, Klappa P, Kietzmann T: The endoplasmic reticulum: Folding, calcium homeostasis, signaling, and redox control. Antioxid Redox Signal 2006, 8(9-10):1391-1418.

39. Rossi D, Barone V, Giacomello E, Cusimano V, Sorrentino V: The sarcoplasmic reticulum: An organized patchwork of specialized domains. Traffic 2008, 9(7):1044-1049

40. Periasamy M, Kalyanasundaram A: SERCA pump isoforms: Their role in calcium transport and disease. Muscle Nerve 2007, 35(4):430-442.

41. Vermassen E, Parys JB, Mauger JP: Subcellular distribution of the inositol 1,4,5-trisphosphate receptors: functional relevance and molecular determinants. Biol Cell 2004, 96(1):3-17.

42. Patterson RL, van Rossum DB, Kaplin Al, Barrow RK, Snyder SH: Inositol 1,4,5-trisphosphate receptor/GAPDH complex augments $\mathrm{Ca} 2+$ release via locally derived NADH. Proc Natl Acad Sci USA 2005, 102(5):1357-1359.

43. Lundholm CE: DDE-induced eggshell thinning in birds: Effects of $p, p^{\prime}$ DDE on the calcium and prostaglandin metabolism of the eggshell gland. Comp Biochem Physiol C 1997, 118(2):113-128.

44. Strehler EE, Zacharias DA: Role of alternative splicing in generating isoform diversity among plasma membrane calcium pumps. Physiol Rev 2001, 81(1):21-50.46.

45. Howard A, Legon S, Walters JRF: Human and rat intestinal plasmamembrane calcium-pump isoforms. Am J Physiol 1993, 265(5):G917-G925.47.

46. Kumar R, Haugen JD, Penniston JT: Molecular-cloning of a plasmamembrane calcium-pump from human osteoblasts. J Bone Miner Res 1993, 8(4):505-513.

47. Philipson KD, Nicoll DA: Sodium-calcium exchange: A molecular perspective. Annu Rev Physiol 2000, 62:111-133.

48. Belkacemi L, Bedard I, Simoneau L, Lafond J: Calcium channels, transporters and exchangers in placenta: a review. Cell Calcium 2005, 37(1):1-8.

49. Herchuelz A, Kamagate A, Ximenes $\mathrm{H}$, Van Eylen F: Role of $\mathrm{Na} / \mathrm{Ca}$ exchange and the plasma membrane $\mathrm{Ca} 2+-$ ATPase in beta cell function and death. Ann N Y Acad Sci 2007, 1099:456-467.

50. Ruknudin AM, Lakattaa EG: The regulation of the $\mathrm{Na} / \mathrm{Ca}$ exchanger and plasmalemmal Ca2+ ATPase by other proteins. Ann N Y Acad Sci 2007, 1099:86-102.

51. Blaustein MP, Juhaszova M, Golovina VA, Church PJ, Stanley EF: Na/Ca exchanger and PMCA localization in neurons and astrocytes - Functional implications. Ann N Y Acad Sci 2002, 976:356-366.

52. Garty H: Molecular-properties of epithelial, amiloride-blockable $\mathrm{Na}+$ channels. FASEB J 1994, 8(8):522-528.

53. Jorgensen PL, Hakansson KO, Karlish SJD: Structure and mechanism of $\mathrm{Na}$, K-ATPase: Functional sites and their interactions. Annu Rev Physiol 2003, 65:817-849.

54. Heitzmann D, Warth R: Physiology and pathophysiology of potassium channels in gastrointestinal epithelia. Physiol Rev 2008, 88(3):1119-1182.

55. Hebert SC, Desir G, Giebisch G, Wang WH: Molecular diversity and regulation of renal potassium channels. Physiol Rev 2005, 85(1):319-371.

56. Warth R: Potassium channels in epithelial transport. Pflugers Arch 2003, 446(5):505-513.

57. Steward MC, Ishiguro H, Case RM: Mechanisms of bicarbonate secretion in the pancreatic duct. Annu Rev Physiol 2005, 67:377-409.

58. Romero MF, Fulton CM, Boron WF: The SLC4 family of $\mathrm{HCO}$ - transporters. Pflugers Arch 2004, 447(5):495-509.

59. Dorwart MR, Shcheynikov N, Yang D, Muallem S: The solute carrier 26 family of proteins in epithelial ion transport. Physiol 2008, 23(2):104-114.

60. Xu J, Henriksnas J, Barone S, Witte D, Shull GE, Forte JG, Holm L, Soleimani M: SLC26A9 is expressed in gastric surface epithelial cells, mediates $\mathrm{Cl}-1$ HCO3- exchange, and is inhibited by NH4+. Am J Physiol Cell Physiol 2005, 289(2):C493-C505.

61. Xu J, Song PH, Miller ML, Borgese F, Barone S, Riederer B, Wang ZH, Alper $S L$, Forte JG, Shull GE, et al: Deletion of the chloride transporter Slc26a9 causes loss of tubulovesicles in parietal cells and impairs acid secretion in the stomach. Proc Natl Acad Sci USA 2008, 105(46):17955-17960.

62. Alper SL: Molecular physiology of SLC4 anion exchangers. Exp Physiol 2006, 91(1):153-161. 
63. Choi JY, Muallem D, Kiselyov K, Lee MG, Thomas PJ, Muallem S: Aberrant CFTR-dependent HCO3- transport in mutations associated with cystic fibrosis. Nature 2001, 410(6824):94-97.

64. Hug MJ, Tamada T, Bridges RJ: CFTR and bicarbonate secretion to epithelial cells. News Physio/ Sci 2003, 18:38-42.

65. Chan HC, Shi QX, Zhou CX, Wang XF, Xu WM, Chen WY, Chen AJ, Ni Y, Yuan YY: Critical role of CFTR in uterine bicarbonate secretion and the fertilizing capacity of sperm. Mol Cell Endocrinol 2006, 250(1-2):106-113.

66. Niggli V, Sigel E, Carafoli E: The Purified Ca-2+ Pump of HumanErythrocyte Membranes Catalyzes an Electroneutral Ca-2+-H+Exchange in Reconstituted Liposomal Systems. J Biol Chem 1982, 257(5):2350-2356.

67. Smallwood JI, Waisman DM, Lafreniere D, Rasmussen H: Evidence That the Erythrocyte Calcium-Pump Catalyzes a Ca-2 + -Nh + Exchange. J Biol Chem 1983, 258(18):1092-1097.

68. Beyenbach KW, Wieczorek H: The V-type H+ATPase: molecular structure and function, physiological roles and regulation. J Exp Biol 2006, 209(4):577-589.

69. Marshansky V, Futai M: The V-type $\mathrm{H}+-$ ATPase in vesicular trafficking: targeting, regulation and function. Curr Opin Cell Biol 2008, 20(4):415-426.

70. Nishi T, Forgac M: The vacuolar $(\mathrm{H}+)$-atpases - Nature's most versatile proton pumps. Nat Rev Mol Cell Biol 2002, 3(2):94-103.

71. Furla P, Galgani I, Durand I, Allemand D: Sources and mechanisms of inorganic carbon transport for coral calcification and photosynthesis. J Exp Biol 2000, 203(22):3445-3457.

72. Bertucci A, Tambutte E, Tambutte S, Allemand D, Zoccola D: Symbiosisdependent gene expression in coral-dinoflagellate association: cloning and characterization of a P-type H(+)-ATPase gene. Proc Biol Sci 2010, 277(1678):87-95.

73. Chang MH, Plata C, Zandi-Nejad K, Sindic A, Sussman CR, Mercado A, Broumand V, Raghuram V, Mount DB, Romero MF: Slc26a9-Anion exchanger, channel and $\mathrm{Na}+$ transporter. J Membr Biol 2009, 228(3):125-140.

74. Jentsch TJ, Stein V, Weinreich F, Zdebik AA: Molecular structure and physiological function of chloride channels. Physiol Rev 2002 82(2):503-568

75. Duran C, Thompson CH, Xiao Q, Hartzell HC: Chloride Channels: Often Enigmatic, Rarely Predictable. Annu Rev Physiol 2010, 72:95-121.

76. Furukawa T, Ogura T, Katayama Y, Hiraoka M: Characteristics of rabbit CIC-2 current expressed in Xenopus oocytes and its contribution to volume regulation. Am J Physiol 1998, 274(2):C500-C512

77. Britton FC, Hatton WJ, Rossow CF, Duan D, Hume JR, Horowitz B: Molecular distribution of volume-regulated chloride channels (CIC-2 and $\mathrm{ClC}-3$ ) in cardiac tissues. Am J Physiol Heart Circ Physiol 2000, 279(5):H2225-H2233.

78. Britton FC, Wang GL, Huang ZM, Ye LD, Horowitz B, Hume JR, Duan DY: Functional characterization of novel alternatively spliced $\mathrm{ClC}-2$ chloride channel variants in the heart. J Biol Chem 2005, 280(27):25871-25880.

79. Huang ZM, Prasad C, Britton FC, Ye LL, Hatton WJ, Duan D: Functional role of CLC-2 chloride inward rectifier channels in cardiac sinoatrial nodal pacemaker cells. J Mol Cell Cardiol 2009, 47(1):121-132.

80. Bosl MR, Stein V, Hubner C, Zdebik AA, Jordt SE, Mukhopadhyay AK Davidoff MS, Holstein AF, Jentsch TJ: Male germ cells and photoreceptors, both dependent on close cell-cell interactions, degenerate upon $\mathrm{ClC}-2 \mathrm{Cl}$ (-) channel disruption. EMBO J 2001, 20(6):1289-1299.

81. Nehrke K, Arreola J, Nguyen HV, Pilato J, Richardson L, Okunade G, Baggs R, Shull GE, Melvin JE: Loss of hyperpolarization-activated Cl- current in salivary acinar cells from Clcn2 knockout mice. J Biol Chem 2002, 277(26):23604-23611.

82. Hebert SC, Mount DB, Gamba G: Molecular physiology of cation-coupled Cl- cotransport: the SLC12 family. Pflugers Arch 2004, 447(5):580-593.

83. Adragna NC, Di Fulvio M, Lauf PK: Regulation of K-Cl cotransport: from function to genes. J Membr Biol 2004, 201(3):109-137.

84. Gamba G: Molecular physiology and pathophysiology of electroneutral cation-chloride cotransporters. Physiol Rev 2005, 85(2):423-493.

85. Lundholm CE, Bartonek M: Furosemide decreases eggshell thicjness and inhibits $45 \mathrm{Ca}^{2+}$ uptale by asubcellular fraction of eggshell gland mucosa of the domestic-Fowl. Comp Biochem Physiol C 1992, 101(2):317-320.
86. Engels WR: Contributing software to the internet - the amplify program. Trends Biochem Sci 1993, 18(11):448-450.

87. Gautron J, Murayama E, Vignal A, Morisson M, McKee MD, Rehault S, Labas V, Belghazi M, Vidal ML, Nys Y: Cloning of ovocalyxin-36, a novel chicken eggshell protein related to lipopolysaccharide-binding proteins, bactericidal permeability-increasing proteins, and plunc family proteins. J Biol Chem 2007, 282(8):5273-5286.

doi:10.1186/1472-6793-12-10

Cite this article as: Jonchère et al.: Identification of uterine ion transporters for mineralisation precursors of the avian eggshell. BMC Physiology 2012 12:10

\section{Submit your next manuscript to BioMed Central and take full advantage of:}

- Convenient online submission

- Thorough peer review

- No space constraints or color figure charges

- Immediate publication on acceptance

- Inclusion in PubMed, CAS, Scopus and Google Scholar

- Research which is freely available for redistribution

Submit your manuscript at www.biomedcentral.com/submit
C Biomed Central 